School of Finance

University of St.Gallen

TAIL RISK IN HEDGE FUNDS: A UNIQUE VIEW FROM PORTFOLIO HELDINGS

Vikas Agarwal

STEFAN RUENZI

FLORIAN WEIGERT

WORKING PAPERS ON FinANCE No. 2015/8

SWISS INSTITUTE OF BANKING AND FINANCE (S/BF - HSG)

MAY 2015 


\title{
Tail risk in hedge funds: A unique view from portfolio holdings
}

\author{
Vikas Agarwal, Stefan Ruenzi, and Florian Weigert*
}

This Version: May 10, 2015

\begin{abstract}
We develop a new tail risk measure for hedge funds to examine the impact of tail risk on fund performance and to identify the sources of tail risk. We find that tail risk affects the cross-sectional variation in fund returns, and investments in both, tailsensitive stocks as well as options, drive tail risk. Moreover, managerial incentives and discretion as well as exposure to funding liquidity shocks are important determinants of tail risk. We find evidence that is consistent with funds being able to time tail risk exposure prior to the recent financial crisis.
\end{abstract}

Keywords: Hedge Funds, Tail Risk, Portfolio Holdings, Funding Liquidity Risk

JEL Classification Numbers: G11, G23

\footnotetext{
*Vikas Agarwal is from Georgia State University, J. Mack Robinson College of Business, 35 Broad Street, Suite 1234, Atlanta GA 30303, USA. Email: vagarwal@gsu.edu.Tel: +1-404-413-7326. Fax: +1-404-413-7312. Vikas Agarwal is also a Research Fellow at the Centre for Financial Research (CFR), University of Cologne. Stefan Ruenzi is from the University of Mannheim, L9, 1-2, 68161 Mannheim, Germany. Email: ruenzi@bwl.uni-mannheim.de. Tel: +49-621-181-1646. Florian Weigert is from the University of St. Gallen, Swiss Institute of Banking and Finance, Rosenbergstrasse 52, 9000 St. Gallen, Switzerland. Email: florian.weigert@unisg.ch. Tel: +41-71-224-7014. We thank George Aragon, Turan Bali, Martin Brown, Stephen Brown, John Cochrane, Andre Güttler, Olga Kolokolova, Jens Jackwerth, Juha Joenväärä, Petri Jylha, Bing Liang, Gunter Löffler, Scott Murray, George Panayotov, Liang Peng, Paul Söderlind, and Fabio Trojani for their helpful comments and constructive suggestions. We benefited from the comments received at presentations at the 6th Annual Conference on Hedge Funds in Paris, the 9th Imperial Conference on Advances in the Analysis of Hedge Fund Strategies, the National Taiwan University, Purdue University, the University of Mannheim, the University of St. Gallen, and the University of Ulm. We would also like to thank Kevin Mullally and Honglin Ren for excellent research assistance.
} 


\section{Tail risk in hedge funds: A unique view from portfolio holdings}

Hedge funds are often described as pursuing trading strategies that generate small positive returns most of the time before incurring a substantial loss akin to "picking up pennies in front of a steam roller" or "selling earthquake insurance" (Duarte, Longstaff, and Yu, 2007; Stulz, 2007). Hedge funds are therefore likely to be exposed to substantial tail risk, i.e., they can incur substantial losses in times when investors' marginal utility is very high. However, there is limited research on whether hedge funds are exposed to tail risk, and if so, how hedge funds' investments and trading strategies contribute to tail risk and how it affects hedge fund performance. Our paper fills this void in the literature by using hedge fund return data as well as the mandatorily reported $13 \mathrm{~F}$ quarterly equity and option holdings of hedge fund firms to examine the sources and performance implications of tail risk. ${ }^{1}$ In particular, we ask the following questions. First, does tail risk explain the cross-sectional variation in hedge fund performance? Second, is tail risk related to certain observable fund characteristics and funds' exposure to funding liquidity shocks? Third, does tail risk in hedge funds arise from their dynamic trading strategies and/or their investments in stocks that are sensitive to equity market crashes? Finally, can hedge funds time tail risk by altering their positions in equities and options before market crashes?

We address these questions by first deriving a new non-parametric estimate for hedge funds' tail risk based on their reported returns. This tail risk measure is defined as the lower tail dependence of hedge funds' returns and the market return, scaled by the ratio of the absolute value of their respective expected shortfalls $(E S)$. The lower tail dependence is defined as the conditional probability that an individual hedge fund has its worst individual return realizations exactly at the same time when the market also has its worst return realizations in a given time span. We show that this tail risk measure has significant predictive power for the cross-section of hedge fund returns. We find that the return spread between the portfolios of hedge funds with the highest and the lowest past tail risk amounts to

\footnotetext{
${ }^{1}$ Institutional investors including hedge funds that exercise investment discretion over $\$ 100$ million of assets in $13 \mathrm{~F}$ securities are required to disclose their long positions in $13 \mathrm{~F}$ securities (common stocks, convertible bonds, and options) on a quarterly basis. They are not required to report any short positions (see Griffin and Xu, 2009; Aragon and Martin, 2012; Agarwal, Fos, and Jiang, 2013; and Agarwal, Jiang, Yang, and Tang, 2013).
} 
4.8\% per annum after controlling for the risk factors in the widely used Fung and Hsieh (2004) 7-factor model. The spread in risk-adjusted returns is even more pronounced $(5.3 \%$ per annum) for equity-oriented hedge fund styles. These spreads are robust to controlling for other risks that have been shown to influence hedge fund returns including correlation risk (Buraschi, Kosowski, and Trojani, 2014), liquidity risk (Aragon, 2007; Sadka, 2010; Teo, 2011), macroeconomic uncertainty (Bali, Brown, and Caglayan, 2014), and volatility risk (Bondarenko, 2004; Agarwal, Bakshi, and Huij, 2009). In addition, results from multivariate regressions confirm that tail risk predicts future fund returns even after controlling for various fund characteristics such as fund size, age, past yearly excess return, standard deviation, skewness, kurtosis, value-at-risk $(V a R), E S$, market beta, delta, lockup period, restriction period, minimum investment, management and incentive fees, and indicator variables for leverage, offshore domicile, hurdle rate, and high watermark. The predictability of future returns extends as far as six months into the future.

We conduct a number of robustness checks to show that these results are not sensitive to several choices that we make in our empirical analysis. Our results are stable when we change the estimation horizon of tail risk, compute tail risk using different cut-off values, use $V a R$ instead of $E S$ in the computation of tail risk, change the weighting procedure in portfolio sorts from equal-weighting to value-weighting, and compute tail risk with daily instead of monthly returns using data for a subsample of hedge funds that report daily data to Bloomberg.

Next, we investigate the determinants of tail risk of hedge funds, i.e., why some funds are more exposed to tail risk than others and which fund characteristics are associated with high tail risk. We document several findings that are consistent with the earlier theoretical and empirical literature on the relation between risk-taking behavior and contractual features of hedge funds. First, we find that the managerial incentives stemming from the incentive fee call option are positively related to funds' tail risk. This result is consistent with the riskinducing behavior associated with the call option feature of incentive fee contracts (Brown, Goetzmann, and Park, 2001; Goetzmann, Ingersoll, and Ross, 2003; Hodder and Jackwerth, 2007). Second, we observe that tail risk is negatively associated with past performance, i.e., worse performing fund managers engage in greater risk-taking behavior. This finding is 
similar to the increase in propensity to take risk following poor performance as documented in Aragon and Nanda (2012). Finally, both the lockup period and leverage exhibit a significant positive relation with tail risk. Since funds with longer lockup period are likely to invest in more illiquid securities (Aragon, 2007), this finding suggests that funds that make such illiquid investments are more likely to be exposed to higher tail risk. Levered funds may use derivatives and short selling techniques to take state-contingent bets that can exacerbate tail risk in such funds.

We also use the bankruptcy of Lehman Brothers in September 2008 as a quasi-natural experiment leading to an exogenous shock to the funding of hedge funds by prime brokers. This allows us to examine a causal relation between funding liquidity risk and tail risk. We find evidence of a greater increase in tail risk of funds that used Lehman Brothers as their prime broker as compared to other funds, indicating that funding liquidity shocks can enhance tail risk.

We next investigate different trading strategies that can induce tail risk in hedge funds to shed light on the sources of tail risk. In particular, we consider (i) dynamic trading strategies captured by exposures to a factor that mimics the return of short out-of-the-money put options on the equity market of Agarwal and Naik (2004) as well as (ii) an investment strategy involving long positions in high tail risk stocks and short positions in low tail risk stocks, i.e., exposure to an equity tail risk factor (Chabi-Yo, Ruenzi, and Weigert, 2015; Kelly and Jiang, 2014). To understand which of these strategies explain the tail risk of hedge funds, we first regress individual hedge funds' returns on the S\&P 500 index put option factor as in Agarwal and Naik (2004) and on the Chabi-Yo, Ruenzi, and Weigert (2015) equity tail risk factor. We then analyze how the cross-sectional differences in hedge funds' overall tail risk can be explained by the funds' exposures to these factors. We find that funds' tail risk is negatively related to the Agarwal and Naik (2004) out-of-the-money put option factor and positively related to the Chabi-Yo, Ruenzi, and Weigert (2015) equity tail risk factor. Ceteris paribus, a one standard deviation decrease (increase) in the put option beta (equity tail risk beta) is associated with an increase of overall tail risk by $0.26(0.13)$. Given an average tail risk of equity-related funds of 0.38 , this translates into an increase of $68 \%$ and $34 \%$ in the tail 
risk for a one standard deviation increase in the sensitivities to the put option factor and the equity tail risk factor, respectively.

Motivated by the positive relation between hedge fund tail risk and return exposure to the equity tail risk factor, we directly analyze hedge fund's investments in common stocks. For this purpose, we merge the fund returns reported in the commercial hedge fund databases to the reported $13 \mathrm{~F}$ equity portfolio holdings of hedge fund firms. We find that there is a positive and highly significant relation between the returns-based tail risk of hedge fund firms and the tail risk of the individual long equity positions of the funds that belong to the respective hedge fund firm. This effect is even more pronounced for levered funds. As mentioned before, the $13 \mathrm{~F}$ filings also consist of long positions in equity options. We analyze these option holdings to corroborate our earlier finding of tail risk being related to a negative exposure to the out-of-the-money put option factor. Furthermore, we generally find a negative relation between returns-based tail risk and the number of different stocks on which put positions are held by funds (as well as the equivalent number and value of equity shares underlying these put positions) in their 13F filings. Taken together, these findings show that tail risk of hedge funds is (at least partially) driven by the nature of hedge funds' investments in tail-sensitive stocks and put options.

Finally, we examine if hedge funds can time tail risk. We start by comparing the tail risk imputed from a hypothetical buy-and-hold portfolio of funds' long positions in equities with the actual tail risk estimated from hedge funds' returns. The idea is to capture how much the funds actively change their tail risk relative to the scenario where they passively hold their equity portfolio. We find that during the recent financial crisis in October 2008, the actual tail risk is significantly lower than the tail risk imputed from the precrisis buy-and-hold equity portfolio. This is consistent with hedge funds reducing their exposure to tail risk prior to the crisis by decreasing their positions in more tail-sensitive stocks. Complementing this finding, we observe that funds increase the number of different stocks on which they hold long put option positions as well as the number and value of the equity shares underlying these put positions before the onset of the crisis. Furthermore, we find that the hedge funds' long put positions are concentrated in stocks with high tail risk. 
We make several contributions to the literature. First, we derive a new measure for hedge funds' tail risk and show that it explains the cross-sectional variation in fund returns. Second, we link tail risk exposures to fund characteristics. Third, we utilize an exogenous shock to the funding of hedge funds through prime broker connections to examine the relation between funding liquidity shocks and tail risk. Fourth, we use the mandatory 13F portfolio disclosures of hedge fund firms to uncover the sources of tail risk by examining funds' investments in equities and options. Finally, we analyze hedge funds' changes in equity and put option holdings to shed light on their ability to time tail risk.

The structure of this paper is as follows. Section 1 reviews the related literature. Section 2 describes the data used in this study. Section 3 presents results on the impact of tail risk on the cross-section of average hedge fund returns. Section 4 sheds light on the relation between hedge funds' characteristics and tail risk. Section 5 explicitly studies if the tail risk is induced by portfolio holdings of hedge funds. Section 6 investigates hedge funds' ability to time tail risk and Section 7 concludes.

\section{Literature Review}

Our study relates to the substantial literature studying the risk-return characteristics of hedge funds. A number of studies including Fung and Hsieh (1997, 2001, 2004), Mitchell and Pulvino (2001), and Agarwal and Naik (2004) show that hedge fund returns exhibit a nonlinear relation with the market return due to their use of dynamic trading strategies. This in turn can expose hedge funds to significant tail risk, which is difficult to diversify (Brown and Spitzer, 2006; Brown, Gregoriou, and Pascalau, 2012). Agarwal, Bakshi, and Huij (2009) document that hedge funds are exposed to higher moments of equity market returns, i.e., volatility, skewness, and kurtosis. Jiang and Kelly (2012) find that hedge fund returns are exposed to extreme event risk. Gao, Gao, and Song (2014) present a different view where hedge funds benefit from exploiting disaster concerns in the market instead of being themselves exposed to the disaster risk. Buraschi, Kosowski, and Trojani (2014) show that hedge fund returns are associated with exposure to correlation risk and that correlation risk has an impact on the cross-section of average hedge fund returns. We contribute to this strand of literature by not only proposing a tail risk measure but also identifying the channels through which hedge funds are exposed to tail risk and the tools they use to manage tail risk. 
Our findings show that in addition to the dynamic trading strategies of hedge funds, investments in more tail-sensitive stocks expose funds to tail risk and taking long positions in put options help funds mitigate tail risk. We also find evidence of hedge funds timing tail risk by reducing their exposure to tail risk by decreasing their positions in tail-sensitive stocks and increasing their positions in put options prior to the recent financial crisis.

Another strand of literature examines the link between the contractual features of hedge funds and funds' performance and risk-taking behavior. Agarwal, Daniel, and Naik (2009) and Aragon and Nanda (2012) show that the managerial incentives from the hedge fund compensation contracts significantly influence funds' performance and risk taking, respectively. However, these studies generally measure hedge fund risk based on hedge fund return volatility, while we focus on tail risk. Aragon (2007) and Agarwal, Daniel, and Naik (2009) show that funds with longer lockup and redemption periods perform better due to their ability to make long-term and illiquid investments. We build on this literature by providing evidence on tail risk in hedge funds being driven both by managerial incentives and redemption restrictions placed on investors.

Our paper also contributes to the literature on the factor timing ability of hedge funds. Chen (2007) and Chen and Liang (2007) study the market timing and volatility timing ability of hedge funds. They find evidence in favor of funds timing both market returns and volatility, especially during periods of market downturns and high volatility. In contrast, Griffin and $\mathrm{Xu}$ (2009) do not find evidence that hedge funds show market timing abilities. Cao, Chen, Liang, and Lo (2013) investigate if hedge funds selectively adjust their exposures to liquidity risk, i.e., time market liquidity. They find that many fund managers systematically reduce their exposure in times of low market liquidity, especially during severe liquidity crises. We extend this literature to show that hedge funds on aggregate are also able to time their exposure to tail risk by reducing their exposure prior to the financial crisis.

\section{Data and Variable Construction}

\subsection{Data}

Our hedge fund data comes from three distinct sources. Our first source of selfreported hedge fund returns is created by merging four commercial databases. We refer to the 
merged database as "Union Hedge Fund Database." The second source is the 13F equity portfolio holdings database from Thomson Reuters (formerly the CDA/Spectrum database). Our third data source consists of hedge funds' long positions in call and put options extracted from the $13 \mathrm{~F}$ filings from the SEC EDGAR (Electronic Data Gathering, Analysis, and Retrieval) database. ${ }^{2}$ Individual stock data comes from the CRSP database.

The Union Hedge Fund Database consists of a merge of four different major commercial databases: Eureka, Hedge Fund Research (HFR), Morningstar, and Lipper TASS and includes data for 25,732 hedge funds from 1994 to 2012. The use of multiple databases to achieve a comprehensive coverage is important since $65 \%$ of the funds only report to one database (e.g., Lipper TASS has $22 \%$ unique funds). ${ }^{3}$ A Venn diagram in Figure 1 shows the overlap across the four databases.

\section{[Insert Figure 1 here]}

To eliminate survivorship bias we start our sample period in 1994, the year in which commercial hedge fund databases started to also track defunct hedge funds. Further, we use multiple standard filters for our sample selection. First, we require a fund to have at least 24 monthly return observations. Second, we filter out funds denoted in a currency other than US dollars. Third, we eliminate the first 12 months of each fund's return series to avoid backfilling bias. Finally, we exclude all funds of hedge funds from our sample. This filtering process leaves us with a final sample of 10,834 hedge funds out of which 6,281 are equityoriented funds. We classify a hedge fund as equity-oriented when its investment strategy is either 'Emerging Markets', 'Event Driven', 'Equity Long-Short', 'Equity Long Only', 'Equity Market Neutral', 'Short Bias' or 'Sector'. Hedge funds employing an investment strategy of 'CTA / Trend-Following', 'Global Macro', 'Multi-Strategy', 'Relative Value', or 'Others' are classified as non-equity oriented funds.

We report the summary statistics of hedge funds' excess returns (i.e., returns in excess of the risk free rate) in Panel A and fund characteristics in Panel B of Table 1, respectively.

[Insert Table 1 around here]

\footnotetext{
${ }^{2}$ In principle, it is possible to also use the long equity positions reported to the SEC and stored in the EDGAR database. However, due to the non-standardized format of $13 \mathrm{~F}$ filings, it is challenging to extract this data. Therefore, we rely on the Thomson Reuters database for the long equity positions.

${ }^{3}$ Agarwal, Daniel, and Naik (2009) show a similar limited overlap between different commercial databases.
} 
The 13F Thomson Reuters Ownership database consists of quarterly equity holdings of 5,536 institutional investors during the period from 1980 (when Thomson Reuters data starts) to 2012. Unfortunately, hedge fund firms are not separately identified in this database. Hence, we follow Agarwal, Fos, and Jiang (2013) to manually classify a 13F filing institution as a hedge fund firm if it satisfies at least one of the following five criteria: (i) it matches the name of one or multiple funds from the Union Hedge Fund Database, (ii) it is listed by industry publications (e.g., Hedge Fund Group, Barron's, Alpha Magazine) as one of the top hedge funds, (iii) on the firm's website, hedge fund management is identified as a major line of business, (iv) Factiva lists the firm as a hedge fund firm, and (v) if the $13 \mathrm{~F}$ filer name is one of an individual, we classify this case as a hedge fund firm if the person is the founder, partner, chairman, or other leading personnel of a hedge fund firm.

Applying these criteria provides us with a dataset of 1,694 unique hedge fund firms among the $13 \mathrm{~F}$ filing institutions. ${ }^{4}$ Next, we merge these firms from the $13 \mathrm{~F}$ filings to the hedge fund firms listed in the Union Hedge Fund Database following Agarwal, Fos, and Jiang (2013). The merging procedure is applied at the hedge fund firm level and entails two steps. First, we match institutions by name allowing for minor variations. Second, we compute the correlation between returns imputed from the $13 \mathrm{~F}$ quarterly holdings and returns reported in the Union Database. We eliminate all pairs where the correlation is either negative or not defined due to lack of overlapping periods of data from both data sources. We end up with 793 hedge fund firms managing 2,720 distinct hedge funds during the period from 1994 to 2012. Since our main focus in this analysis is on equity-related hedge funds, it is comforting to notice that $70.4 \%$ of $13 \mathrm{~F}$ filing hedge fund firms are classified as equityrelated fund firms in the Union Database.

Finally, we merge our sample with the quarterly $13 \mathrm{~F}$ filings of long option positions of these hedge fund firms in the period from the first quarter of 1999 (when electronic filings became available from the SEC EDGAR database) to the last quarter of 2012. The 13F filing institutions have to report holdings of long option positions on individual $13 \mathrm{~F}$ securities (i.e.,

\footnotetext{
${ }^{4}$ This number might appear low at first glance but is significant when considered in the context of the size of the industry. The total value of equity positions held by $13 \mathrm{~F}$ hedge funds is $\$ 2.52$ trillion which is equivalent to $88 \%$ of the size of the hedge fund industry in 2012 according to HFR.
} 
stocks, convertible bonds, and options). ${ }^{5}$ Institutions are required to provide information whether the options are calls or puts and what the underlying security is, but do not have to report an option's exercise price or maturity date. We find that out of the 793 hedge fund firms (which appear both in the $13 \mathrm{~F}$ equity portfolio database and the Union database), 406 firms file at least one long option position during our sample period. We use this sample in Sections 5 and 6 to investigate the relation between a fund firm's returns-based tail risk and tail risk induced from long positions in equities and options.

\subsection{Tail Risk Measure}

To evaluate an individual fund's tail risk, we measure the extreme dependence between a fund's self-reported return and the value-weighted CRSP equity market return. In particular, we first define a fund's tail sensitivity (TailSens) via the lower tail dependence of its return $r_{i}$ and the CRSP value-weighted market $r_{m}$ return using

$$
\text { TailSens }=\lim _{q \rightarrow 0} P\left(r_{i} \leq F_{i}^{-1}(q) \mid r_{m} \leq F_{m}^{-1}(q)\right),
$$

where $F_{i}\left(F_{m}\right)$ denotes the marginal distribution function of the returns of hedge fund $i, r_{i}$ (the market return $r_{m}$ ) in a given period and $q \in(0,1)$ is the argument of the distribution function. According to this measure, funds with high TailSens are likely to have their lowest return realization at the same time when the equity market realizes its lowest return, i.e., these funds are particularly sensitive to market crashes. ${ }^{6}$ However, this measure does not take into account how bad the worst return realization of the hedge fund really is. Thus, in a second step, to account for the severity of poor hedge fund returns, we define a hedge fund's tail risk (TailRisk) as

\footnotetext{
${ }^{5}$ See https://www.sec.gov/divisions/investment/13ffaq.htm for more details.

${ }^{6}$ Longin and Solnik (2001) and Rodriguez (2007) apply the lower tail dependence coefficient to analyze financial contagion between different international equity markets. Chabi-Yo, Ruenzi, and Weigert (2015) use lower tail dependence to analyze asset pricing implications of extreme dependence structures in the bivariate distribution of a single stock return and the market return. Our focus in this paper is on the equity tail risk in hedge funds but in priniciple, our approach can be extended to other asset markets such as bonds, currencies, and commodities. However, due to the lack of data on hedge funds' holdings in these other assets, it is not possible to analyze the nature of holdings as a potential channel for tail risk, which is one of the key contributions of our study.
} 


$$
\text { TailRisk }=\text { TailSens } \cdot \frac{\left|E S_{r_{i}}\right|}{\left|E S_{r_{m}}\right|}
$$

where $E S_{r_{i}}$ and $E S_{r_{m}}$ denote the expected shortfall (also sometimes referred to as conditional $V a R$ ) of the hedge fund return and the market return, respectively. ES has been used in several hedge fund studies as a univariate risk measure to account for downside risk (see, e.g., Agarwal and Naik (2004) and Liang and Park (2007, 2010) for a discussion of the superiority of $E S$ over $V a R)$. Taking the ratio of $E S$ of individual funds with respect to the $E S$ of the market allows us to measure a fund's tail risk relative to that of the market. ${ }^{7}$

We estimate TailRisk for hedge fund $i$ in month $t$ based on a rolling window of 24 monthly returns. The estimation is performed non-parametrically purely based on the empirical return distribution function of hedge fund $r_{i}$ and the value-weighted CRSP equity market $r_{m}$ with a cut-off of $\mathrm{q}=0.05$. We also use a cut-off of $\mathrm{q}=0.05$ for the computation of $E S_{r_{i}}$ and $E S_{r_{m}} \cdot{ }^{8}$ As an example of our estimation procedure, consider the time period from January 2007 to December 2008. The fifth percentile of the market return distribution consists of the two worst realizations which occurred in September $2008(-9.24 \%)$ and October 2008 (-17.23\%). To compute TailSens for hedge fund $i$ during January 2007 to December 2008, we analyze whether the two worst return realizations of hedge fund $i$ occur at the same time as these market crashes, i.e., in September 2008 and October 2008. If none, one, or both of the fund's two worst return realizations occur in September 2008 and/or October 2008, we compute TailSens for hedge fund $i$ in the period from January 2007 to December 2008 as zero, 0.5, or 1, respectively. TailRisk for hedge fund $i$ in the period from January 2007 to December 2008 is then subsequently defined as the product of TailSens and the absolute value of the fraction between hedge fund $i$ 's $E S$ and the market return's ES

\footnotetext{
${ }^{7}$ This ratio is reminiscent of market beta in the context of the CAPM, the M-squared measure (Modigliani and Modigliani, 1997) and the Graham and Harvey's GH1 and GH2 (1996, 1997) measures often used for performance evaluation.

${ }^{8}$ The specific choice of an estimation horizon of 24 months and a cut-off of $q=0.05$ does not influence our results. We obtain similar results when we apply different estimation horizons of 36 months and 48 months as well as cut-off points of $q=0.10$ and $q=0.20$, respectively. We later report these results in Table 3 .
} 
during the same 24-month period. We report summary statistics of our TailRisk measure in Panel C of Table 1.

Panel $\mathrm{C}$ of Table 1 shows that average TailRisk is 0.30 across all hedge funds in the sample. Among the different hedge fund strategies, TailRisk is lowest for Short Bias, Equity Market Neutral, and Relative Value hedge funds and highest for Emerging Markets, Equity Long Only, and Sector hedge funds. Moreover, TailRisk is twice as high for equity-related hedge funds (0.38) compared to non-equity related funds (0.19).

We now inspect the behavior of aggregate TailRisk over time. Aggregate TailRisk is computed as the monthly cross-sectional, equally-weighted average of TailRisk across all hedge funds in the sample. Figure 2 plots the time series of aggregate TailRisk together with aggregate TailRisk of equity-related and non-equity related hedge funds.

[Insert Figure 2 here]

Visual inspection shows that the time-series variation in our tail risk measure corresponds well with known crisis events in financial markets. The highest spike in aggregate TailRisk occurs in October 2008, one month after the bankruptcy of Lehman Brothers and the beginning of a worldwide recession. Additional spikes correspond to the beginning of the Asian financial crisis in autumn 1996 and the Russian financial crisis along with the collapse of Long Term Capital Management (LTCM) in August 1998.

We also look at the correlations between aggregate TailRisk and hedge fund specific risk factors (see Panel D in Table 1). Aggregate TailRisk is moderately positively related to the correlation swap factor of Buraschi, Kosowski, and Trojani (2014) and the Chicago Board Options Exchange (CBOE) volatility index (VIX) as well as moderately negatively related to the market return, the Pástor and Stambaugh (2003) aggregate liquidity risk factor, and the Bali, Brown, and Caglayan (2014) macroeconomic uncertainty factor. Interestingly, we find a high correlation of 0.49 between aggregate TailRisk and the TED Spread (i.e., the difference between the interest rates for three-month U.S. Treasury and three-month Eurodollar contracts) indicating that tail risk of hedge funds and funding liquidity are strongly interconnected. Later in the paper, we will take a closer look at the relationship between TailRisk and funding liquidity in Section 4. In particular, we will assess the impact of a 
funding liquidity shock due to the Lehman Brothers bankruptcy in September 2008 on tail risk of hedge funds that had a prime brokerage relation with Lehman.

\section{Tail risk and hedge fund performance}

\subsection{Does tail risk have an impact on the cross-section of future hedge fund returns?}

Tail risk induced by nonlinearities in hedge fund returns can contribute to fund returns. ${ }^{9}$ To evaluate the predictive power of differences in hedge fund's tail risk on the cross-section of average future hedge fund returns, we relate hedge fund returns in month $t+1$ to hedge fund TailRisk in month $t$. We first look at equal-weighted univariate portfolio sorts. For each month $t$, we sort hedge funds into decile portfolios based on TailRisk. We then compute monthly average excess returns of these portfolios at time $t+1$. We also repeat this analysis separately for the subsample of equity-related hedge funds and non-equity related hedge funds. Panel A of Table 2 reports the results.

\section{[Insert Table 2 here]}

The numbers in the first column show considerable cross-sectional variation in TailRisk across funds. Average TailRisk ranges from virtually zero in the lowest decile up to above 2 in the highest decile. The second column shows that hedge funds with high TailRisk have significantly higher future returns than those with low TailRisk. Hedge funds in the portfolio with the lowest (highest) TailRisk earn a monthly excess return (in excess of the risk-free rate) of $0.45 \%(1.01 \%)$. The return spread between portfolios 1 and 10 is $0.56 \%$ per month, which is statistically significant at the $5 \%$ level with a $t$-statistic of 2.02 . We also estimate alphas for each of the decile portfolios and the difference (10-1) portfolio using the Carhart (1997) four-factor model and the Fung and Hsieh (2004) seven-factor model. We find that the spread between portfolios 10 and 1 remains significantly positive after controlling for other risk factors in these models, and are of similar order of magnitude as the excess returns with 4-factor and 7-factor alphas amounting to $0.53 \%$ and $0.40 \%$ per month, respectively. These spreads translate into an economically large return premium of $6.36 \%$ and $4.80 \%$ per annum, respectively.

\footnotetext{
${ }^{9}$ The underlying intuition is that strategies with a payoff concave to the benchmark (i.e., the market return) earn stable premiums in normal times but lose money during bad times. Goetzmann, Ingersoll, Spiegel, and Welch (2007) demonstrate that such strategies can reduce the utility of standard performance measures such as Sharpe ratios.
} 
Repeating the portfolio sorts for the subsamples of equity-related and non-equity related hedge funds, our results indicate that the premium for TailRisk is driven by the equityrelated funds. For example, controlling for the seven factors in the Fung and Hsieh (2004) model, for the equity-related hedge funds, we obtain a return spread between portfolios 10 and 1 of $0.44 \%$ per month which is statistically significant at the $5 \%$ level with a $t$-statistic of 2.00. In contrast, we do not find a statistically significant return spread for the non-equity related hedge funds (spread of $0.07 \%$ per month with a $t$-statistic of 0.35 ). This makes sense as our tail risk measure is based on the worst returns in the equity market. Therefore, in the rest of the paper we focus on the subsample of equity-related hedge funds.

In Panel B, we explore the robustness of our results after controlling for other risk factors that have been shown to be important in explaining hedge fund performance. To do so, we regress the 10-1 TailRisk return portfolio on various extensions of the Fung and Hsieh (2004) model. For the sake of comparison, we report the results of the Fung and Hsieh (2004) seven-factor model as our baseline model in the first column (which corresponds to the results from Column (7) in Panel A). In the second column, we then include the MSCI Emerging Markets return as an additional risk factor. In columns three and four, we add the HML and UMD factors from the Carhart (1997) model to control for book-to-market and momentum. To control for liquidity exposure of hedge funds, we include the Pástor and Stambaugh (2003) traded liquidity factor in the fifth column. In columns six to eight, we control for the exposures to the Bali, Brown, and Caglayan (2014) macroeconomic uncertainty factor, the Buraschi, Kosowski, and Trojani (2014) correlation risk factor, and the VIX (as in Agarwal, Bakshi, and Huij, 2009), respectively. In each case, we continue to observe a significant positive alpha of our 10-1 TailRisk return portfolio ranging from $0.36 \%$ to $0.54 \%$ per month. These findings further corroborate the importance of tail risk in explaining the cross-section of hedge fund returns.

In Panel C, we report the results of regressions of excess fund returns in month $t+1$ on TailRisk and other fund characteristics measured in month $t$ using the Fama and MacBeth (1973) methodology. We specify:

$$
r_{i, t+1}=\alpha+\beta_{1} \text { TailRisk }_{i, t}+\beta_{2} X_{i, t}+\varepsilon_{i, t},
$$


where $r_{i, t+1}$ denotes fund $i$ 's excess return in month $t+1$, TailRisk $k_{i, t}$ a fund's tail risk, and $X_{i, t}$ is a vector of fund characteristics. We use the Newey and West (1987) adjustment with 24 lags to adjust standard errors for serial correlation. Fund characteristics include fund size (computed as a fund's natural logarithm of assets under management), age (in months), past yearly excess return, standard deviation, skewness, kurtosis, VaR, ES, market beta (all computed over the past 24 months), delta, lockup period (in months), restriction period (computed as the sum of a fund's notice period and redemption period), minimum investment, management and incentive fees, and indicator variables for leverage, offshore domicile, hurdle rate, and high watermark. Controlling for these fund characteristics, we find a positive impact of TailRisk on future hedge fund returns. Depending on the regression specification, the coefficient estimate for TailRisk ranges from 0.217 to 0.451 with $t$-statistics ranging from 1.85 to 3.37 . These results confirm that the relation between future fund returns and tail risk is not subsumed by fund characteristics and other risk measures including higher moments of fund returns and fund's systematic risk.

So far we have examined the ability of tail risk to predict next month's fund returns. A natural question is how far this predictability goes. Panel D reports the results of regressions of future excess returns over different horizons on TailRisk after controlling for various fund characteristics measured in month $t$. We find that TailRisk can significantly predict future fund returns up to six months into the future.

In summary, we find that TailRisk has strong predictive power to explain the crosssectional variation in hedge fund returns. Hedge funds with high tail risk outperform their counterparts by around 5\% per annum after adjusting for risk factors from the Fung and Hsieh (2004) seven-factor model. We show that this premium persists even after controlling for additional recently proposed risk factors (such as liquidity risk, macroeconomic uncertainty, correlation risk, and volatility risk) and fund characteristics.

\subsection{Robustness checks}

To further corroborate our results in Table 2, we now briefly report results from additional robustness checks on the relation between TailRisk of hedge funds in month $t$ and average fund returns in month $t+1$. Specifically, we investigate the stability of our results by 
(i) changing the estimation horizon of the TailRisk measure from 2 years to either 3 years or 4 years, (ii) computing TailRisk using different cut-off values (10\% or $20 \%$ instead of $5 \%$ ) to define the worst returns, (iii) using VaR instead of ES in the computation of TailRisk, (iv) applying a value-weighted sorting procedure instead of an equal-weighted sorting procedure, and (v) using daily returns instead of monthly returns to estimate tail risk for a subsample of funds that report daily returns to Bloomberg. ${ }^{10}$ Panel A in Table 3 reports the results from univariate portfolio sorts using these alternative specifications. We only report returns of the $(10-1)$ difference portfolio between hedge funds with the highest TailRisk and hedge funds with the lowest TailRisk, after adjusting for the risk factors in the Fung and Hsieh (2004) seven-factor model.

\section{[Insert Table 3 here]}

In specifications (1) through (6), we look at the results of equal-weighted portfolio sorts when we change the estimation horizon of the TailRisk measure, compute TailRisk using different cut-off values, and use VaR instead of ES in the computation of TailRisk. In specification (7) we show the findings for the value-weighted portfolio sorts and specification (8) reports the results when daily returns instead of monthly returns are used to estimate TailRisk. ${ }^{11}$ Panel B reports the results of Fama and MacBeth (1973) regression (similar to those from Panel D in Table 2) of future excess returns in month $t+1$ on TailRisk and different fund characteristics measured in month $t$ using the same alternatve specifications as above. We only report the coefficient estimate for the impact of TailRisk. The other controls are included in the regressions, but supressed in the table. For ease of comparison, we report the baseline results from Table 2 in the first column of Panels A and B of Table 3. Across all robustness checks, we continue to observe a positive and statistically significant impact of TailRisk on future fund returns.

\footnotetext{
${ }^{10}$ For this purpose, we use a subsample of 444 hedge funds that report daily returns to Bloomberg between 2003 and 2012. In the spirit of Kolokolva and Mattes (2014), we use two filters: (i) restrict our sample to funds with an average daily reporting difference smaller or equal than two days and a maximum gap of seven days, and (ii) require at least 15 daily return observations per month and at least two years of return data per fund. To prevent that our results are driven by outliers, we winsorize daily returns that exceed $100 \%$. Further, we require an overall number of at least 30 hedge funds per month which excludes the months before 2003 in our empirical analysis.

${ }^{11}$ Due to the lower sample size of hedge funds that report daily returns to Bloomberg, we report results of the (3-1) tercile difference portfolio instead of the (10-1) decile difference portfolio.
} 


\section{Determinants and Sources of Tail Risk}

\subsection{Tail Risk and Fund Characteristics}

Section 3 documents that tail risk is an important factor to explain the cross-sectional variation in hedge fund returns. We now investigate which fund characteristics are associated with high tail risk. Besides fund characteristics like size, age, and domicile, we mainly focus on a fund manager's incentives and discretion which have been shown to be related to the risk-taking behavior of fund managers (Brown, Goetzmann, and Park, 2001; Goetzmann, Ingersoll, and Ross, 2003; Hodder and Jackwerth, 2007; Aragon and Nanda, 2012). We estimate regressions of TailRisk of hedge fund $i$ in month $t+1$ on fund $i$ 's characteristics measured in month $t$ again using the Fama and MacBeth (1973) methodology. Specifically, we estimate:

$$
\text { TailRisk }_{i, t+1}=\alpha+\beta_{1} X_{i, t}+\varepsilon_{i, t},
$$

where TailRisk $k_{i, t+1}$ denotes fund $i$ 's tail risk in month $t+1$, and $X_{i, t}$ is a vector of fund characteristics including the same variables as those from regression equation (3). To adjust the standard errors for serial correlation, we use the Newey and West (1987) adjustment with 24 lags. ${ }^{12}$ Table 5 reports the results.

\section{[Insert Table 4 here]}

In model (1), we include fund characteristics such as fund age, size, delta, as well as past yearly return and standard deviation as independent variables. We observe a significantly positive relation between TailRisk and fund age, delta, and standard deviation of returns, and a significantly negative relation with past yearly returns. These findings are consistent with risk-inducing behavior associated with the call option feature of the incentive fee contract (Goetzmann, Ingersoll, and Ross, 2003; Hodder and Jackwerth, 2007; Aragon and Nanda, 2012; Agarwal, Daniel, and Naik, 2009). Moreover, managers seem to respond to poor recent performance by increasing tail risk (Brown, Goetzmann, and Park, 2001).

In model (2), we include fund characteristics such as a hedge fund's lockup and restriction period, minimum investment, management and incentive fee, as well as indicator variables for leverage, offshore domicile, hurdle rate, and high watermark. Consistent with

\footnotetext{
${ }^{12}$ We obtain similar results if we use non-overlapping data and apply standard OLS regressions with monthly time dummies and standard errors clustered by funds. Results are available upon request.
} 
the notion that funds with longer lockup period have greater discretion in managing their portfolios, we observe a positive relation between TailRisk and a fund's lockup period. In addition, we find a negative relation between TailRisk and a fund's incentive fee. Although surprising at first sight, this result is consistent with Agarwal, Daniel, and Naik (2009) who find that incentive fees by themselves do not capture managerial incentives as two different managers that change the same incentive fee rate could be facing different dollar incentives depending on the timing and magnitude of investors' capital flows, funds' return history, and other contractual features.

Finally, in model (3), we include all the fund characteristics together. We continue to observe that TailRisk exhibits a significant positive relation with delta, return standard deviation, and lockup period, as well as a negative relation with past yearly returns. In presence of delta, the coefficient on incentive fee is not significant anymore, consistent with the findings in Agarwal, Daniel, and Naik (2009). In this specification, we also document a positive association between a fund's leverage and TailRisk. This finding is intuitive since leveraged funds are likely to be particularly vulnerable when faced with funding liquidity shocks and systemic crises that force them to deleverage at the worst time. In the next subsection, we formally test this possibility using the quasi-natural experiment of Lehman's bankruptcy.

Our findings are also meaningful based on economic significance. For example, we find that one standard deviation change in a fund's delta is associated with an increase of 0.046 in TailRisk. In contrast, a one standard deviation increase in past yearly returns decreases TailRisk by 0.076 . These figures are economically significant considering that the average tail risk for equity-related hedge funds is 0.38 (see Panel $\mathrm{C}$ of Table 1).

\subsection{Tail risk and funding liquidity: Evidence from Lehman-connected hedge funds}

Panel D of Table 1 shows that aggregate TailRisk is strongly correlated to the TED spread which has been previously used as a proxy for aggregate funding liquidity (e.g., Teo, 2011). However, the correlation by itself does not shed light on the causal relation between funding liquidity risk and tail risk. For this purpose, we assess the impact of a funding liquidity shock due to the Lehman Brothers bankruptcy in September 2008 on the tail risk of 
hedge funds that had a prime brokerage relation with Lehman during this month as compared to the hedge funds without such a relation.

To identify the hedge funds that had Lehman Brothers as their prime broker, we use a snapshot of the Lipper TASS database in 2007. ${ }^{13}$ Lipper TASS data contains information on the prime broker, along with other affiliated companies (e.g., custodian bank) for each hedge fund. We can identify 60 hedge funds that report Lehman Brothers as their prime broker in 2007 and report monthly returns during the financial crisis in 2008-2009.

We compute TailRisk for the 39 equity-related funds out of the 60 Lehman-connected funds and 1,516 equity-related non-Lehman funds from the TASS database in the period from September 2007 to August 2010. We emphasize the impact of the Lehman Brothers bankruptcy in September 2008 by estimating TailRisk based on a shorter horizon of 12 months. ${ }^{14}$ To test if TailRisk of Lehman-connected funds display a larger spike than TailRisk of their counterparts, we construct a matched sample of non-Lehman funds using the propensity score from a logistic model. We estimate a logistic regression of an indicator variable that is equal to one if a hedge fund is Lehman-connected on different fund characteristics (the same fund characteristics as in Table 5), and zero otherwise. We then match each Lehman-connected hedge fund with its closest neighbour based on the estimated propensity score. As an additional robustness check we create a second control group based on a hedge fund's style as well as TailRisk, size, and monthly excess return in August 2007. To do so, we independently sort all funds within their investment strategy based on TailRisk, size, and returns in August 2007 into decile portfolios. We then match each Lehmanconnected hedge fund with a non-connected fund of the identical investment style in the same TailRisk, size and return decile. ${ }^{15}$

Figure 3 displays the evolution of aggregate TailRisk for Lehman-connected equityrelated hedge funds and the two matched control samples of non-Lehman funds during the period from September 2007 to August 2010.

\footnotetext{
${ }^{13}$ A similar setting is used by Aragon and Strahan (2012). They find that stocks held by Lehman-connected hedge funds experienced greater declines in market liquidity following the bankruptcy as compared to other stocks.

${ }^{14}$ We obtain similar results when we use our usual estimation horizon of 24 months to estimate TailRisk.

${ }^{15}$ In the case that this matching procedure does not yield one-to-one matches, we randomly assign a nonconnected hedge fund out of the possible matches to a Lehman-connected fund.
} 
[Insert Figure 3 around here]

Figure 3 shows that, although both Lehman-connected and non-Lehman funds experience a spike in TailRisk in September 2008, the spike is much more pronounced for the Lehmanconnected funds.

We then compare the averages of TailRisk of Lehman-connected funds and the two matched samples of non-Lehman funds in the pre-Lehman crisis period (September 2007 to August 2008), the crisis period (September 2008 to August 2009), and the post-crisis period (September 2009 to August 2010). Panel A of Table 5 reports the results.

[Insert Table 5 around here]

If our matching between Lehman-connected funds and non-Lehman funds is close enough, we should not observe any difference in the tail risk between these funds prior to the bankruptcy. Panel A confirms that this is indeed the case for the pre-bankruptcy period (Precrisis). However, we find a significant difference in TailRisk in the period directly after the Lehman bankruptcy from September 2008 to August 2009 (Crisis). Lehman-connected hedge funds display an aggregate TailRisk of 0.82 whereas the propensity-score-matched (style-, TailRisk-, size-, and returns-matched) non-Lehman funds display an aggregate TailRisk of 0.57 (0.55). The difference in aggregate TailRisk of $0.25(0.27)$ is economically large and statistically significant at the 5\% level with a $t$-statistic of 2.01 (2.25). Finally, in Period 3 from September 2009 to August 2010, we observe that the tail risk averages of the different groups of funds are statistically indistinguishable from each other again. Together, these results show that the exogenous shock to the funding liquidity due to Lehman's bankruptcy leads to a sharp jump in the tail risk of funds that had a prime brokerage relation with Lehman.

To test whether these univariate findings hold in a multivariate setting after controlling for fund characteristics, we also conduct a difference-in-differences analysis by estimating the following regression for the sample covering the Lehman hedge funds and the respective matched samples (based on the same criteria as above) of non-connected Lehman funds: 


$$
\begin{aligned}
\Delta \text { TailRisk }_{i, t}= & \alpha+\beta_{1} \Delta_{\text {Postcrisis-Crisis }}+\beta_{2} \Delta_{\text {Crisis-Precrisis }} \times \text { Lehman }+\beta_{3} \Delta_{\text {Postcrisis-Crisis }} \times \text { Lehman } \\
& +\kappa X_{i, t-1}+\varepsilon_{i, t}
\end{aligned}
$$

where $\Delta$ TailRisk $k_{i, t}$ denotes the change in tail risk for hedge fund $i$ between the pre-Lehman crisis and the crisis period, or between the crisis and the post-crisis period, respectively. $\Delta_{\text {Crisis-Precrisis }}$ and $\Delta$ are indicator variables for the period between the crisis and precrisis, and post-crisis and crisis, respectively. ${ }^{16}$ Lehman is an indicator variable to identify funds that have a prime brokerage relation with Lehman Brothers. $X_{i, t-1}$ is a vector of fundspecific control variables including the fund characteristics also used above in Table 4, all measured at time $t-1$. As expected, the coefficient estimate for the interaction term between Lehman and $\Delta$ is significantly positive. This indicates that hedge funds with a prime brokerage relation with Lehman experience a significantly more pronounced increase in tail risk in the crisis period as compared to the funds from the matched sample. We obtain this finding irrespective of which matched sample of funds without a prime brokearge relationship with Lehman we use and whether we include additional controls or not. The significantly negative coefficient estimate for the interaction of $\Delta$ with Lehman suggests that this effect is (at least partially) subsequently reversed.

\subsection{Sources of Tail Risk}

So far we have investigated which fund characteristics are associated with hedge funds' tail risk. In this section, we take a closer look and examine the channels through which hedge funds may be exposed to tail risk. In particular, we consider two channels. First, as shown in Agarwal and Naik (2004), dynamic trading by hedge funds can contribute to tail risk. ${ }^{17}$ Second, explicit investments in tail-sensitive stocks can be another source of tail risk in hedge funds. To capture the impact of the first channel, we estimate funds' exposure to the out-of-the-money (OTM) put option factor. We follow Agarwal and Naik (2004) to compute

\footnotetext{
${ }^{16}$ We do not include an un-interacted indicator variable for the Precrisis-Crisis period as the constant already reflects the base case of the TailRisk change of between these two periods for funds from the matched sample without a prime brokerage relation with Lehman.

${ }^{17}$ Specifically, they show that it is the nature of funds' dynamic trading corresponding to their investment styles, rather than direct positions in options, that contributes to the tail risk that they capture by an OTM put option factor.
} 
the return of a strategy that involves buying OTM put options on the S\&P composite index with two months to maturity at the beginning of each month and selling them at the beginning of the next month. For the second channel, we use the Chabi-Yo, Ruenzi, and Weigert (2015) high minus low lower tail dependence (LTD)-risk factor as a proxy for tail risk induced by equity holdings. The LTD-risk factor is constructed as the return of a trading strategy going long in stocks with high tail risk exposure (i.e., stocks in the top quintile of crash sensitivity) and going short in stocks with low tail risk exposure (i.e., stocks in the bottom quintile of crash sensitivity). ${ }^{18}$ To control for tail risk potentially induced by other trading strategies of funds, we also compute funds' exposures to the Agarwal and Naik (2004) OTM call option factor, the Fung and Hsieh (2004) trend-following factors, ${ }^{19}$ the Bali, Brown, and Caglayan (2014) macroeconomic uncertainty factor, the Buraschi, Kosowski, and Trojani (2014) correlation risk factor, and the VIX.

We estimate hedge fund $i$ 's univariate exposures to different risk factors for month $t$ based on a rolling window of 24 monthly returns. In a second step, we estimate Fama and MacBeth (1973) regressions at the individual hedge fund level of tail risk in month $t$ (as defined in Section 2) on the exposures to the Agarwal and Naik (2004) put option factor and the Chabi-Yo, Ruenzi, and Weigert (2015) LTD-risk factor in month $t$ :

$$
\text { TailRisk }_{i, t}=\alpha+\lambda_{1} \beta_{\text {OTMPut }, i, t}+\lambda_{2} \beta_{L T D-R i s k, i, t}+\lambda_{3} \beta_{X, i, t}+\varepsilon_{i, t},
$$

where TailR isk $_{i, t}$ is fund $i$ 's tail risk, $\beta_{\text {OTM Put }}\left(\beta_{L T D-R \text { Isk }}\right)$ denotes the univariate exposure to the Agarwal and Naik (2004) out-of-the-money (OTM) put option factor (the Chabi-Yo, Ruenzi, and Weigert (2015) equity tail risk factor) and $\beta_{X}$ is a vector of exposures to the other risk factors described above. To adjust the standard errors for serial correlation, we use the Newey and West (1987) adjustment with 24 lags. Since we perform a two-step estimation procedure, we correct the standard errors for the errors-in-variables problem using the Shanken (1992) correction. Table 6 reports the results of this regression.

\section{[Insert Table 6 here]}

\footnotetext{
${ }^{18}$ Chabi-Yo, Ruenzi, and Weigert (2015) compute the tail risk of individual stocks based on the lower tail dependence of an individual stock return and the market return.

${ }^{19}$ Fung and Hsieh $(2001,2004)$ construct the trend-following factors as the returns on lookback straddles on bonds, currencies, commodities, interest rate, and equities.
} 
In model (1), we regress tail risk on funds' exposure to the Agarwal and Naik (2004) out-of-the-money (OTM) put option factor $\left(\beta_{\text {OTM Put }}\right)$. We find that tail risk is strongly negatively related to $\beta_{\text {отм Риt }}$ with a slope coefficient of -12.46 , which indicates that tail risk is positively related to a trading strategy of writing out-of-the-money put options on the equity market index. ${ }^{20}$ This relation is statistically significant at the $1 \%$ level with a $t$-statistic of -3.63 . Model 2 investigates the relation of tail risk and $\beta_{L T D R i s k}$, the sensitivity to the Chabi-Yo, Ruenzi, and Weigert (2015) high minus low LTD-Risk factor. We find a highly significant positive relation between tail risk and $\beta_{L T D \text { Risk }}$ (coefficient of $0.630 ; t$-statistic $=$ 10.31), which indicates that tail risk is related to a trading strategy of buying stocks with high tail risk and selling stocks with low tail risk. In model 3, we regress TailRisk on funds' sensitivites to both, the OTM put option factor and the equity tail risk factor. We continue to find that tail risk is positively related to $\beta_{L T D \text { Risk }}$ and negatively related to $\beta_{O T M P U t}$. Finally, in model (4), we regress TailRisk on the complete set of hedge fund return sensitivites. Our main results remain unchanged: We still observe that tail risk is driven by a fund's sensitivity to the OTM put option factor and the equity tail risk factor. A one standard deviation increase in $\beta_{L T D R i s k}$ increases a fund's tail risk by 0.13 , while a one standard deviation decrease in $\beta_{\text {OTM PUt }}$ increases a fund's tail risk by 0.26 .

\section{Tail Risk and Portfolio Holdings}

\subsection{Tail risk induced from equity holdings of hedge funds}

Our results hitherto suggest that a hedge fund's tail risk is induced by both dynamic trading as well as by portfolio holdings of stocks with high equity tail risk. We now dig deeper and investigate whether we can find direct evidence of the sources of funds' tail risk using their disclosed $13 \mathrm{~F}$ portfolio holdings that include long positions in equities. To establish direct evidence between tail risk induced by equity holdings and tail risk estimated from hedge fund returns, we use the Thomson Reuters 13F database that provides common stock holdings of more than 5,000 institutional managers with 100 million or more in $13 \mathrm{~F}$

\footnotetext{
${ }^{20}$ This result also suggests that tail risk can be reduced by a trading strategy of holding long put options. Later in Section 5 of the paper, we investigate the relation between actual long put option positions of hedge funds and their tail risk.
} 
securities (i.e., equities, convertible bonds, and options). The database provides long equity holdings of 1,694 manually classified hedge fund firms. The merge between the Union Hedge Fund Database and the 13F portfolio holdings follows Agarwal, Fos, and Jiang (2013) as explained earlier in Section 2. Our final sample consists of 793 hedge fund firms managing 2,720 distinct hedge funds during the period from 1994 to 2012.

Since portfolio holdings are reported at the hedge fund firm level, we first compute excess return of hedge fund firm $i$ in month $t$ as the value-weighted reported excess returns of the firm's individual hedge funds. We then compute a hedge fund firm $i$ 's tail risk in month $t$ based on the firm's reported excess returns and the market using an estimation horizon of 24 months. Second, using the $13 \mathrm{~F}$ equity portfolio holdings, we compute the excess equity portfolio return of a hedge fund firm as the value-weighted excess returns of the firm's disclosed stock positions. Specifically, to obtain a return series of monthly observations, we use hedge fund firm $i$ 's disclosed equity positions in month $t$ to compute the equity portfolio return over months $t+1$ to $t+3$. As an example, we use the disclosed portfolio positions of hedge fund $i$ at the end of December 2011 to compute the equity portfolio return for the months from January 2012 to March 2012. To compute the equity portfolio return for the months from April 2012 to June 2012, we then use the disclosed positions at the end of March 2012, and so on. Finally, we calculate a hedge fund firm $i$ 's equity tail risk in month $t$ based on the firm's equity portfolio returns and the market using an estimation horizon of 24 months. We also estimate different risk characteristics from a firm's equity portfolio returns such as the standard deviation, skewness, kurtosis, ES, market beta, as well as upside and downside beta (defined as market beta when the market is above and below, respectively, its median return realization; see Ang, Chen, and Xing, 2006). In addition, we compute different portfolio firm characteristics using the value-weighted average of liquidity, size, book-tomarket, and past yearly return of the underlying stocks.

To analyze the relation between hedge funds' tail risk from reported returns and equity tail risk estimated from disclosed equity positions, we estimate Fama and MacBeth (1973) regressions. We regress tail risk of hedge fund firm $i$ in month $t$ on hedge fund firm $i$ 's holdings-based portfolio equity tail risk in month $t$ controlling for different equity portfolio risk and firm characteristics using the Newey and West (1987) adjustment with 24 lags: 


$$
\text { TailRisk }_{i, t}=\alpha+\beta_{1} \text { Equity TailRisk }_{i, t}+\beta_{2} X_{i, t}+\varepsilon_{i, t},
$$

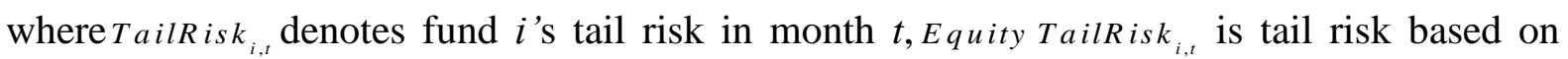
equity portfolio holdings as described above and $x_{i, t}$ is a vector of equity portfolio risk and fund characteristics. Table 7 reports the results.

\section{[Insert Table 7 here]}

In model (1), we use equity tail risk as the only explanatory variable. It has a positive impact and is highly statistically significant at the $1 \%$ level. This finding provides direct evidence of a strong positive relation between a hedge fund's tail risk and tail risk induced by its equity holdings. In models (2) to (5), we expand our specification to control for various portfolio characteristics. In model (2), we add return standard deviation, skewness, kurtosis, $E S$, market beta (all based on disclosed holdings). Our results reveal that fund tail risk is also positively related to market beta but shows no statistically significant relation to any of the other controls. When we split market beta into upside beta and downside beta in model (3), we find the intuitive result that downside beta is driving this finding. These results also hold in model (4), where we include, liquidity, size, book-to-market, and past yearly returns (again all based on disclosed equity holdings) as additional controls. More importantly, in all regressions, equity tail risk is significantly positively related to tail risk estimated from fund returns at the $1 \%$ level.

The impact of equity tail risk is also economically important. We find that a one standard deviation increase of equity tail risk increases fund tail risk by 0.07 . This implies a relative increase of almost $20 \%$ as the tail risk for equity-related funds is 0.38 (see Panel $\mathrm{C}$ of Table 1). This is the largest effect in terms of economic magnitude of all variables included in model (4).

Models (1) to (4) ignore the possible impact of fund firm leverage in the relation between equity tail risk and fund tail risk. Intuitively, equity tail risk should matter more if the hedge fund firm employs a higher level of equity leverage. To account for this issue, we follow Farnsworth (2014) and compute a hedge fund firm $i$ 's long-only leverage in month $t$ as the market capitalization of equity portfolio positions divided by firm i's assets under 
management. ${ }^{21}$ In model (5), we add the interaction of equity tail risk with this long-only leverage measure as an additional independent variable. As expected, we find this interaction term to be positive and statistically significant.

In summary, this section shows that tail risk of hedge funds is to a significant extent directly induced by tail risk of their long equity positions.

\subsection{Tail risk and option holdings of hedge funds}

In addition to tail risk induced from long equity holdings, we had earlier found that a hedge fund's sensitivity to an out-of-the-money put option factor was one of the main factors to explain fund tail risk in Table 7. Since 13F filings only include long positions in options, we cannot observe if hedge funds explicitly write out-of-the-money put options that would exacerbate their tail risk. However, we can investigate whether some hedge fund firms reduce their tail risk by holding long positions in put options.

To test this hypothesis we use option holdings data from 13F filings from the SEC EDGAR database. Specifically, we analyze long call and put option holdings of the 793 hedge fund firms in our sample during the period from the first quarter of 1999 to the last quarter of 2012. We find that during this period 51.2\% of hedge fund firms in our sample (i.e., 406 of 793 firms) file at least one long option position. To merge fund firms that disclose their option positions quarterly with monthly fund firm tail risk estimates, we again use the convention that disclosed positions in month $t$ are carried forward for the subsequent months $t+1$ to $t+3$.

To investigate if holding long put options reduces fund tail risk, we compute for hedge fund firm $i$ in month $t$, (a) the number of different stocks on which funds hold put positions, (b) the equivalent number of equity shares underlying these put positions (in millions), and (c) the equivalent value of equity shares underlying these put positions (in millions). ${ }^{22}$ Unfortunately, the data does not contain information that would allow us to calculate the actual value of the option positions, which is why we rely on these coarser

\footnotetext{
${ }^{21}$ In order to reduce the impact of outliers, we winsorize our measure of long-only leverage at the $1 \%$ level.

${ }^{22}$ We illustrate these measures with an example: Assume that a fund holds put options on 10,000 shares of stock A that trades at $\$ 30$ and 5,000 shares of stock B that trade at $\$ 20$. Then, (i) the number of stocks on which put options are held is 2, (ii) the equivalent number of equity shares underlying the put positions is 15,000 , and (iii) the equivalent value of equity shares underlying these put positions is $\$ 400,000$.
} 
measures of option use. We winsorize the number and the value of equity shares at the $1 \%$ level to mitigate the influence of outliers.

In our sample, the average number of different stocks on which put (call) positions are held is 3.54 (3.55), the number of equity shares underlying the put (call) positions is 1.59 (1.61) million, and the value of equity shares underlying the put (call) positions is $\$ 18.13$ (\$17.89) million. ${ }^{23}$

We regress tail risk of hedge fund firm $i$ in month $t$ on fund firm $i$ 's option holdings in month $t$ using the Newey and West (1987) adjustment with 24 lags. Table 8 reports the results.

\section{[Insert Table 8 here]}

In models (1) through (3), we regress tail risk on the number of different call and put options, the number of shares underlying these call and put options, and the value of shares underlying these call and put options, respectively. We find that the number of shares underlying the put options and the value of shares underlying the put options significantly reduce fund firms' tail risk. There is never any significant impact of the call option positions. In model (4), we estimate a regression of fund firms' tail risk jointly on all variables regarding hedge funds' derivative exposure. We find that both the number of put options and the value of shares underlying the put options significantly reduce a hedge fund firm's tail risk. A one standard deviation increase in the number of put options (value of shares underlying the put options) reduces fund tail risk by an economically significant value of $0.13(0.08)$. Again, none of the call option variables has a significant impact. Overall, these results provide at least some suggestive evidence that hedge fund firms can reduce tail risk by taking long positions in put options.

\section{Tail Risk Timing: Evidence from the Financial Crisis in $\mathbf{2 0 0 8}$}

In the last part, we now investigate whether hedge funds possess tail risk timing ability. Although hedge funds with high tail risk on average outperform funds with low tail risk, they earn very low returns during market downturns. As an example, we observe that the

\footnotetext{
${ }^{23}$ Please note that in our empirical analysis we retain all fund firms in the sample that do not disclose long option holdings at all. This reduces the average number and value of equity shares underlying the option positions considerably. Our main results regarding the relation between tail risk and long put holdings remain unaffected whether we include or exclude these firms.
} 
decile of hedge funds with the highest tail risk (measured in September 2008 based on the previous 24 months) underperforms the decile of hedge funds with the lowest tail risk by $20.82 \%$ during October 2008, which is the worst financial crisis during our sample period with a CRSP value-weighted market return of $-17.23 \% .{ }^{24}$ Hence, being able to reduce tail risk before severe market crises would be particularly beneficial.

To examine whether funds exhibit tail risk timing ability, we examine their equity and option positions shortly before and during October 2008. We first study funds' timing ability with regard to their equity positions. To do so, we look at funds' equity portfolio holdings and compare differences between actual equity tail risk and hypothetical equity tail risk for the sample of equity-related hedge fund firms during the financial crisis of October $2008 .^{25}$ To estimate hypothetical equity tail risk for hedge fund firm $i$, we look at its portfolio disclosures six months before the worst market crash happened, in March 2008. We then compute hypothetical tail risk for hedge fund firm $i$ over the following year under the assumption that the fund manager did not change the fund's portfolio composition and continued to hold the same portfolio as in March 2008. In contrast, actual tail risk is computed as before based on actual portfolio holdings information updated over time. Figure 4 plots the development of aggregate actual equity tail risk (taken over all equity-related hedge fund firms in our sample) and aggregate hypothetical equity tail risk during the period from March 2008 to March 2009.

\section{[Insert Figure 4 here]}

Figure 4 shows that actual aggregate actual equity tail risk is lower than aggregate hypothetical equity tail risk beginning from August 2008 onwards and remains so until March 2009. We also perform a mean comparison test between hedge fund firms' actual tail risk and hypothetical tail risk in October 2008 in Panel A of Table 9.

[Insert Table 9 here]

\footnotetext{
${ }^{24}$ Looking at all months in our sample period with a market return of smaller than $-10 \%$ (six months in total), we find that the decile portfolio of hedge funds with the highest tail risk underperforms the decile portfolio with the lowest tail by $-10.41 \%$. This spread is statistically significant at the $5 \%$ level (with a $t$-statistic of -3.14 ).

${ }^{25}$ Given the relatively short sample period, we choose this approach rather than using the timing factor in a multifactor model that has also been used in the literature (e.g., Chen, 2007; Chen and Liang, 2007; and Cao, Chen, Liang, and Lo, 2013).
} 
Our results indicate that in October 2008, the aggregate hypothetical equity tail risk of hedge funds was 1.19 while aggregate actual equity tail risk of funds was 1.11 . The difference of 0.08 is statistically significant at the one percent level with a $t$-statistic of 3.60. These findings show that the average fund did reduce its tail risk exposure by investing less in stock long positions that have high tail exposure prior to the crisis (i.e. between March and September 2008).

In the next step, we analyze whether hedge funds also used options to time tail risk, i.e. whether they increased their long positions in put options before October 2008. We plot the number of different stocks in which funds hold put options and the number and value of equity shares underlying the put positions of hedge funds during the period from March 2008 to March 2009 in Figure 5.

\section{[Insert Figure 5 here]}

We find that hedge funds increase both the number of different stocks on which funds hold put options as well as the number and value of equity shares underlying the put positions substantially from March 2008 to December 2008. Subsequently, they reduce these positions again. Panel B of Table 9 formalizes these observations in performing a mean comparison test between the number of different stocks in which funds hold put options (the number of equity shares underlying the put positions, the value of equity shares underlying the put positions) in March 2008 and October 2008. Our results reveal that the number of different stocks with put positions (the number of equity shares underlying the put positions, the value of equity shares underlying the put positions) in March 2008 was 4.14 (1.51 million, \$26.25 million), whereas this number amounts to 5.90 (2.71 million, $\$ 36.53$ million) in October 2008. The difference amounts to 1.76 (1.20 million, $\$ 10.28$ million) and is statistically significant at the five percent level or better with a $t$-statistic of $2.03(3.14,4.51)$, showing that hedge funds on average increased their long positions in puts. ${ }^{26}$

Next, we investigate whether hedge funds hold put options on exactly those stocks that have higher tail risk. For this purpose, we compute for each stock $i$ in October 2008, (a) the number of different hedge funds that hold put positions on this stock, (b) the overall

\footnotetext{
${ }^{26}$ The increasing number of put option positions of hedge funds between March 2008 and October 2008 is not driven by increases in funds' size. Actually, the average assets under management of hedge funds is $\$ 872.55$ million in March 2008, which reduces to \$715.67 million in October 2008.
} 
number of equity shares held by different hedge funds underlying the put positions (in millions) on this stock, and (c) the overall value of equity shares held by different hedge funds underlying the put positions (in \$ millions) on this stock. Then, we regress these stocklevel put option measures on tail risk and different stock characteristics measured in September 2008.

Panel $\mathrm{C}$ of Table 9 reports the regression results using standard errors clustered by stock. Models (1) through (3) show the results of univariate regressions. We find that the higher the tail risk of a stock, the higher the number of different hedge funds holdings put positions on this stock and the higher is the overall number and value of equity shares underlying these put positions.

These effects could also be driven by the size of the respective stock (as larger stocks might be simply more likely to appear in hedge fund portfolios) or by hedge fund preferences for certain stock characteristics. Thus, in models (4) through (6), we additionally control for firm size and additional firm and return characteristics of the stocks. When controlling for these characteristics, we do not find a significant impact of equity tail risk on the number of equity shares underlying the put positions anymore. However, the impact remains statistically significant at the $1 \%$ and $10 \%$ level, respectively, for the number of different funds holding put positions on this stock and the overall value of equity shares underlying the put positions.

Finally, we examine whether differences in timing abilities across hedge fund firms are also reflected in cross-sectional performance differences. To address this issue, we sort hedge fund firms into tercile portfolios based on their tail risk timing ability. In particular, we use four different metrics for these sorts, which we also used in our previous analysis on aggregate timing ability. First, we take the difference of actual equity tail risk and hypothetical equity tail risk timing in October 2008. Second, we take the difference in the number of different stocks in which funds hold put options as well as the number and value of equity shares underlying the put positions between October 2008 and March 2008. We then compute the excess returns of these portfolios in October 2008 and assess return differences between portfolio 3 (good timers) and portfolio 1 (bad timers). Results are reported in Panel D. We find that the good timers' portfolios indeed outperform the bad 
timers' portfolios using all four metrics of tail risk timing ability with statistically significant spreads ranging from $3.61 \%$ to $5.06 \%$.

To summarize, our results in this section are consistent with hedge funds reducing tail risk before the market crash of September 2008 by either reducing equity tail risk or increasing their positions in put options, particularly on stocks with high tail risk. Furthermore, if funds did so to a larger extent, this is also reflected in significantly better performance as compared to other funds.

\section{Conclusion}

It has been well documented that hedge funds use dynamic trading strategies and take state-contingent bets that can expose them to tail risk. In this paper, we propose a nonparametric measure of tail risk to show that equity-related hedge funds with high tail risk outperform equity-related funds with low tail risk by $5.3 \%$ per annum even after controlling for various risk factors in the Fung and Hsieh (2004) 7-factor model. Moreover, we find that tail risk can predict future hedge fund returns up to a horizon of six months. We then dig deeper to uncover the sources of tail risk and find it to be strongly related to a fund's exposure to a put writing strategy on the equity market as well as to an equity-based tail risk factor. Using hedge funds' mandatory disclosure of long equity positions, we provide evidence on a strong direct link between funds' tail risk and their investments in tail-sensitive stocks. We also show that funds that take more long positions in equity put options exhibit lower tail risk. Our results therefore suggest that both, funds' investments in stocks with high tail risk as well as their dynamic trading strategies, contribute to the tail risk.

We show that certain hedge fund characteristics are related to funds' tail risk. Specifically, tail risk is positively related to the delta, lockup period, and leverage of a fund. We also find evidence of a greater increase in tail risk during the 2008 financial crisis of funds that used Lehman Brothers as their prime broker compared to other funds, indicating that funding liquidity shocks can enhance tail risk.

Finally, we find that during the recent financial crisis in October 2008, the actual tail risk of hedge funds is significantly lower than the tail risk imputed from a hypothetical buyand-hold equity portfolio based on their disclosed positions prior to the onset of the crisis. Moreover, we observe an increase in the long positions in put options of hedge funds prior to 
October 2008. These findings suggests that hedge funds on average successfully reduced their exposure to tail risk prior to the onset of the crisis and indicates that hedge funds seem to possess some tail risk timing skills. 


\section{References}

Agarwal, Vikas, and Narayan Y. Naik, 2004, Risks and portfolio decisions involving hedge funds, Review of Financial Studies 17, 63-98.

Agarwal, Vikas, Gurdip Bakshi, and Joop Huij, 2009, Do higher-moment equity risks explain hedge fund returns? Working Paper, Erasmus University, Georgia State University, and University of Maryland.

Agarwal, Vikas, Naveen D. Daniel, and Narayan Y. Naik, 2003, Flows, performance, and managerial incentives in the hedge fund industry, Working Paper, Georgia State University and London Business School.

Agarwal, Vikas, Naveen D. Daniel, and Narayan Y. Naik, 2009, Role of managerial incentives and discretion in hedge fund performance, Journal of Finance 64, 2221-2256.

Agarwal, Vikas, Vyacheslav Fos, and Wei Jiang, 2013, Inferring reporting-related biases in hedge fund databases from hedge fund equity holdings, Management Science 59, 1271-1289.

Agarwal, Vikas, Wei Jiang, Yuehua Tang, and Baozhong Yang, 2013, Uncovering hedge fund skill from the portfolios they hide, Journal of Finance 68, 739-783.

Ang, Andrew, Joseph Chen, and Yuhang Xing, 2006, Downside risk, Review of Financial Studies 19, 1191-239.

Aragon, George O., 2007, Share restrictions and asset pricing: Evidence from the hedge fund industry, Journal of Financial Economics 83, 33-58.

Aragon, George O., and J. Spencer Martin, 2012, A unique view of hedge fund derivatives usage: Safeguard or speculation? Journal of Financial Economics 105, 436-456.

Aragon, George O., and Vikram Nanda, 2012, Tournament behavior in hedge funds: Highwater marks, fund liquidation, and managerial stake, Review of Financial Studies 25, 937-974.

Aragon, George O., and Philip E. Strahan, 2012, Hedge funds as liquidity providers: Evidence from the Lehman bankruptcy, Journal of Financial Economics 103, 570-587.

Bali, Turan G., Stephen J. Brown, and Mustafa O. Caglayan, 2014, Macroeconomic risk and hedge fund returns, Journal of Financial Economics, 114, 1-19. 
Bondarenko, Oleg, 2004, Market price of variance risk and performance of hedge funds, Working Paper, University of Illinois.

Brown, Stephen J., and Jonathan F. Spitzer, 2006, Caught by the tail: Tail risk neutrality and hedge fund returns, Working Paper, New York University.

Brown, Stephen J., William N. Goetzmann, and James Park, 2001, Careers and survival: competition and risk in the hedge fund and CTA industry, Journal of Finance 56, 1869-1886.

Brown, Stephen J., Greg N. Gregoriou, and Razvan Pascalau, 2012, Is it possible to overdiversify? The case of funds of hedge funds, Review of Asset Pricing Studies 2, 89-110.

Buraschi, Andrea, Robert Kosowski, and Fabio Trojani, 2014, When there is no place to hide: correlation risk and the cross-section of hedge fund returns, Review of Financial Studies 27, 581-616.

Cao, Charles, Yong Chen, Bing Liang, and Andrew W. Lo, 2013, Can hedge funds fund time market liquidity? Journal of Financial Economics 109, 493-516.

Carhart, Mark, 1997, On Persistence in Mutual Fund Performance, Journal of Finance 52, $57-82$.

Chabi-Yo, Fousseni, Stefan Ruenzi, and Florian Weigert, 2015, Crash sensitivity and the cross-section of expected stock returns, Working Paper, Ohio State University, University of Mannheim, and University of St. Gallen.

Chen, Yong, 2007, Timing ability in the focus market of hedge funds, Journal of Investment Management 5, 66-98.

Chen, Yong, and Bing Liang, 2007, Do market timing hedge funds time the market? Journal of Financial and Quantitative Analysis 42, 827-856.

Duarte, Jefferson, Francis Longstaff, and Fan Yu, 2007, Risk and return in fixed income arbitrage: nickels in front of a steamroller? Review of Financial Studies 20, 769-811.

Fama, Eugene F., and Kenneth R. French, 1993, Common risk factors in the returns on stocks and bonds, Journal of Financial Economics 33, 3-56.

Fama, Eugene F., and James D. MacBeth, 1973, Risk, return, and equilibrium: empirical tests, Journal of Political Economy 81, 607-636. 
Farnsworth, Grant, 2014, Strategic hedge fund leverage and investor welfare: A holdingsbased approach, Working Paper, Penn State University

Fung, William, and David A. Hsieh, 1997, Empirical characteristics of dynamic trading strategies: The case of hedge funds, Review of Financial Studies 10, 275-302.

Fung, William, and David A. Hsieh, 2001, The risk in hedge fund strategies: theory and evidence from trend followers, Review of Financial Studies 14, 313-341.

Fung, William, and David A. Hsieh, 2004, Hedge fund benchmarks: A risk-based approach, Financial Analysts Journal 60, 65-80.

Gao, George P., Pengjie Gao, and Zhaogang Song, 2014, Do hedge funds exploit rare disaster concerns?, Working Paper, Cornell University and the University of Notre Dame.

Goetzmann, William N., Jonathan E. Ingersoll, and Stephen A. Ross, 2003, High-water marks and hedge fund management contracts, Journal of Finance 58, 1685-1717.

Goetzmann, William N., Jonathan E. Ingersoll, Matthew Spiegel, and Ivo Welch, 2007, Portfolio performance manipulation and manipulation-proof performance measures, Review of Financial Studies 58, 1503-1546.

Graham, John R., and Campbell R. Harvey, 1996, Market timing ability and volatility implied in investment newsletters' asset allocation recommendations, Journal of Financial Economics 42, 397-422.

Graham, John R., and Campbell R. Harvey, 1997, Grading the performance of market-timing newsletters, Financial Analysts Journal 53, 54-66.

Griffin, John M., and Jin Xu, 2009, How smart are the smart guys? A unique view from hedge fund stock holdings, Review of Financial Studies 22, 2331-2370.

Hodder, James E., and Jens C. Jackwerth, 2007, Incentive contracts and hedge fund management, Journal of Financial and Quantitative Analysis 42, 811-826.

Jiang, Hao, and Bryan Kelly, 2012, Tail risk and hedge fund returns, Working Paper, Erasmus University Rotterdam and University of Chicago Booth School of Business.

Kelly, Bryan, and Hao Jiang, 2014, Tail risk and asset prices, Review of Financial Studies 27 , $2841-2871$. 
Kolokolova, Olga, and Achim Mattes, 2014, Recovering Managerial Risk Taking from Daily Hedge Fund Returns: Incentives at Work? University of Manchester and University of Konstanz.

Liang, Bing, and Hyuna Park, 2007, Risk measures for hedge funds: a cross-sectional approach, European Financial Management 13, 333-370.

Liang, Bing, and Hyuna Park, 2010, Predicting hedge fund failure: A comparison of risk measures, Journal of Financial and Quantitative Analysis 45, 199-222.

Longin, Francois, and Bruno Solnik, 2001, Extreme correlation of international equity markets, Journal of Finance 56, 649-676.

Mitchell, Mark, and Todd Pulvino, 2001, Characteristics of risk and return in risk arbitrage, Journal of Finance 56, 2135-2175.

Modigliani, Franco, and Leah Modigliani, 1997, Risk-adjusted performance, Journal of Portfolio Management 23, 45-54.

Newey, Whitney K., and Kenneth D. West, 1987, A simple, positive semi-definite, heteroskedasticity and autocorrelation consistent covariance matrix, Econometrica 55, $703-708$.

Panageas, Stavros, and Mark Westerfield, 2009, High-water marks: High-risk appetites? Convex compensation, long horizons, and portfolio choice, Journal of Finance 64, 1-36.

Pástor, Luboš, and Robert Stambaugh, 2003, Liquidity risk and expected stock returns, Journal of Political Economy 111, 642-685.

Rodriguez, Juan C., 2007, Measuring financial contagion: A copula approach, Journal of Empirical Finance 14, 401-423.

Sadka, Ronnie, 2010, Liquidity risk and the cross-section of hedge fund returns, Journal of Financial Economics 98, 54-71.

Shanken, Jay, 1992, On the estimation of beta-pricing models, Review of Financial Studies 5, $1-33$.

Stulz, Rene, 2007, Hedge funds: past, present, and future, Journal of Economic Perspectives 21, 175-194.

Teo, Melvyn, 2011, The liquidity risk of liquid hedge funds, Journal of Financial Economics $100,24-44$. 


\section{Figure 1: Venn Diagram of the Union Hedge Fund Database}

The Union Hedge Fund Database contains a sample of 25,732 hedge funds created by merging four commercial databases: Eureka, HFR, Morningstar, and Lipper TASS. This figure shows the percentage of funds covered by each database individually and by all possible combinations of multiple databases.

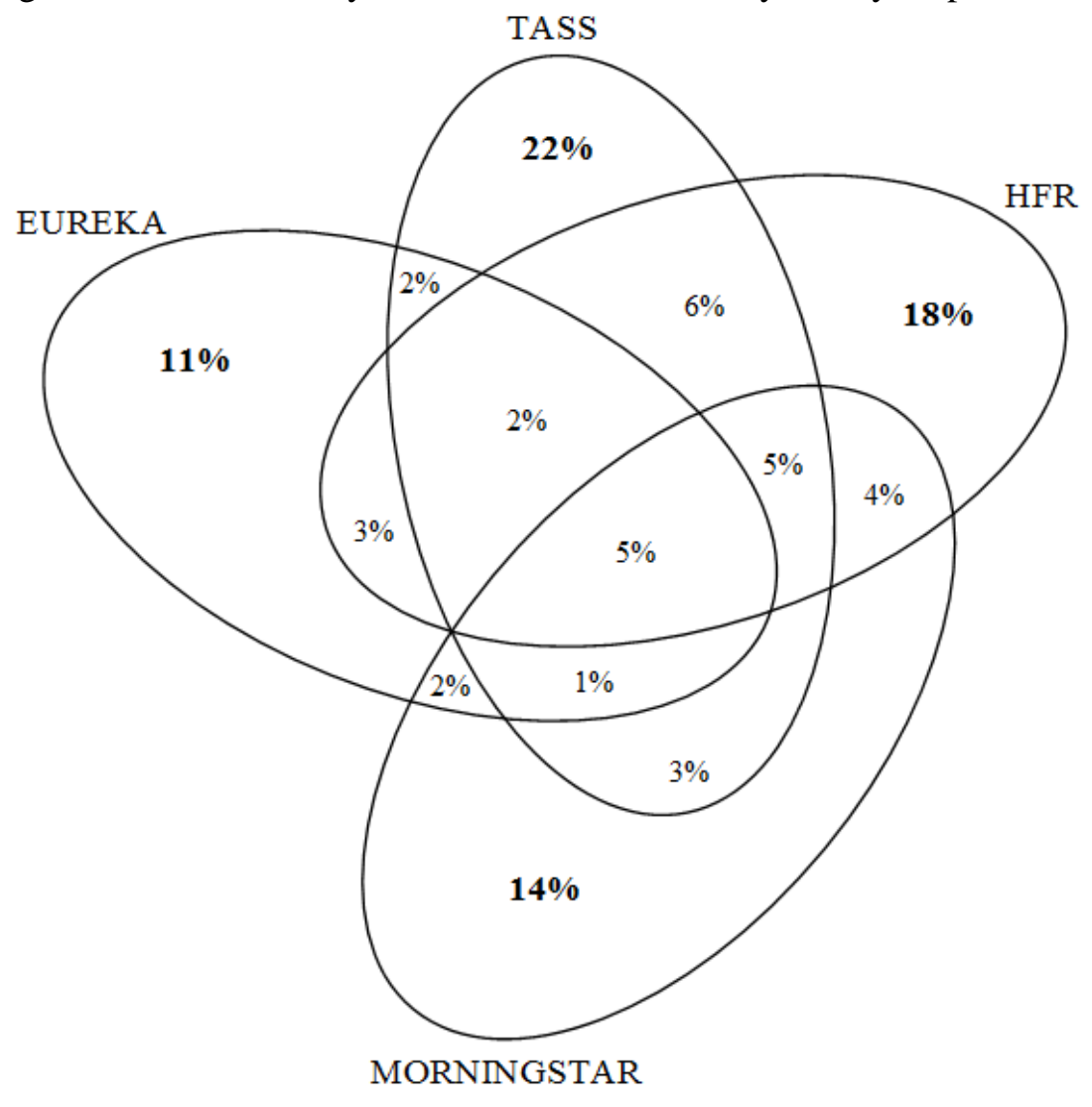




\section{Figure 2: Aggregate Hedge Fund Tail Risk over Time}

This figure displays the evolution of aggregate TailRisk over time. Aggregate TailRisk is defined as the monthly cross-sectional, equally-weighted average of the individual TailRisk measures over all hedge funds in our sample. We also show aggregate TailRisk separately for all equity-related and non-equity related hedge funds. Our sample covers hedge funds from the Union Hedge Fund Database constructed from combining Eureka, HFR, Morningstar, and Lipper TASS databases. The sample period is from January 1994 to December 2012.

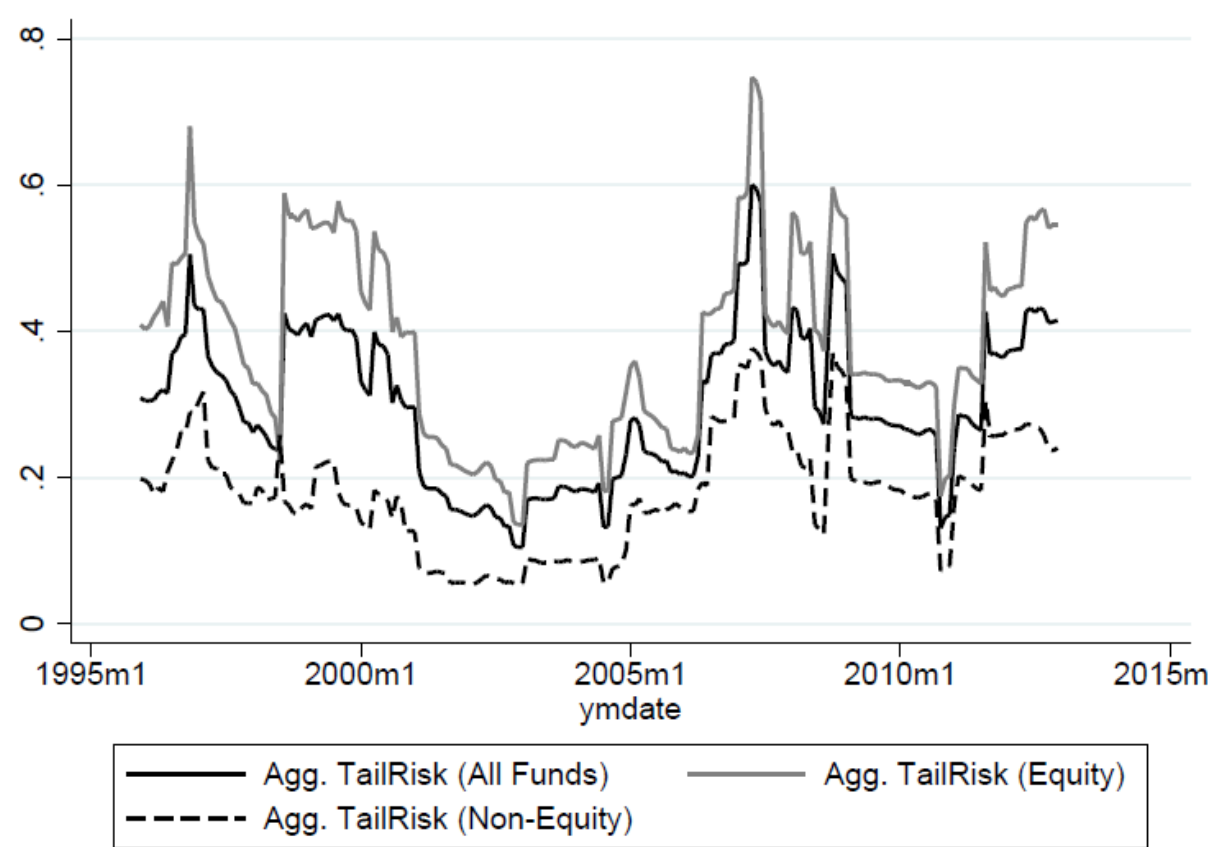




\section{Figure 3: Tail Risk and Funding Liquidity: Evidence From Lehman Brothers connected Hedge Funds}

This figure displays the evolution of aggregate TailRisk for equity-related hedge funds that had Lehman Brothers as a prime broker until September 2008 (solid line) and two matched samples of non-Lehman funds (dotted and dashed lines) from the Lipper TASS database during the period from September 2007 to August 2010. The dashed line corresponds to the first matched sample (Match1) using the propensity score from a model determining the choice of Lehman as a prime broker while the dotted line relates to the second matched sample (Match2) based on the same style and the same TailRisk, size, and past monthly excess return decile in August 2007. We estimate TailRisk each month based using prior 12 months of fund returns.

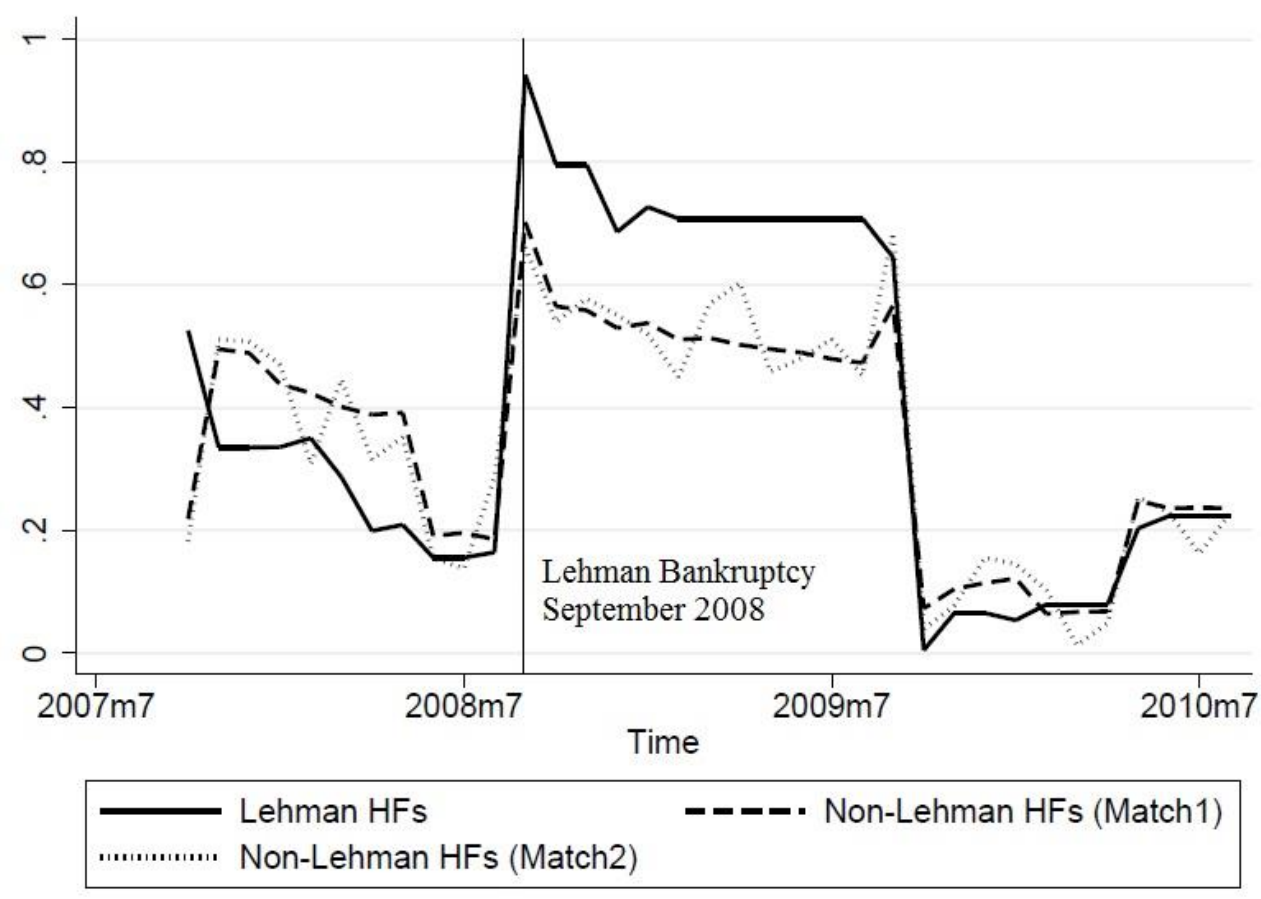




\section{Figure 4: Tail Risk Timing: Evidence From Equity Holdings in the Financial Crisis 2008}

This figure displays the evolution of aggregate actual TailRisk of hedge fund firms' disclosed long equity holdings (dashed line) and the evolution of aggregate hypothetical TailRisk based on hedge funds firms' disclosed long equity holdings from March 2008 (solid line) during the period from March 2008 to March 2009. We estimate TailRisk each month based using prior 24 months of returns. Our sample covers hedge fund firms from the Union Hedge Fund Database constructed from combining Eureka, HFR, Morningstar, and Lipper TASS databases who report 13F long equity holdings to the SEC.

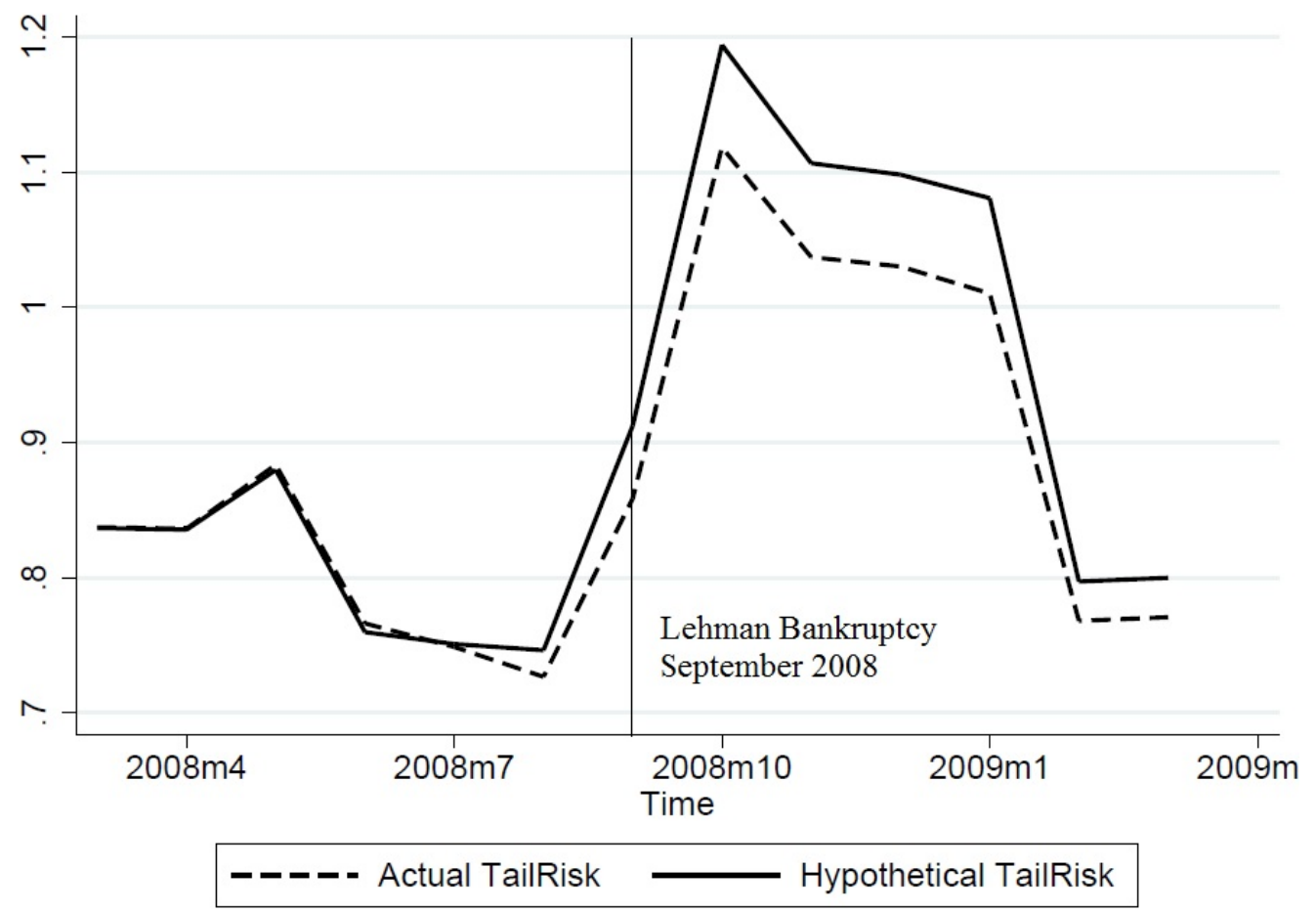




\section{Figure 5: Tail Risk Timing: Evidence From Derivative Holdings in the Financial Crisis 2008}

This figure displays the evolution of the average number of different stocks on which hedge funds hold put positions (Different Put Options, solid line) per hedge fund firm, the average number of equity shares (in millions) underlying the put positions of hedge funds (Stocks Underlying Put Options, dotted line) per hedge fund firm, and the average value of equity shares (in ten-millions) underlying the put positions of hedge funds (Value of Stocks Underlying Put Options, dashed line) per hedge fund firm during the period from March 2008 to March 2009. Our sample covers hedge fund firms from the Union Hedge Fund Database constructed from combining Eureka, HFR, Morningstar, and Lipper TASS databases who report 13F long derivative holdings to the SEC.

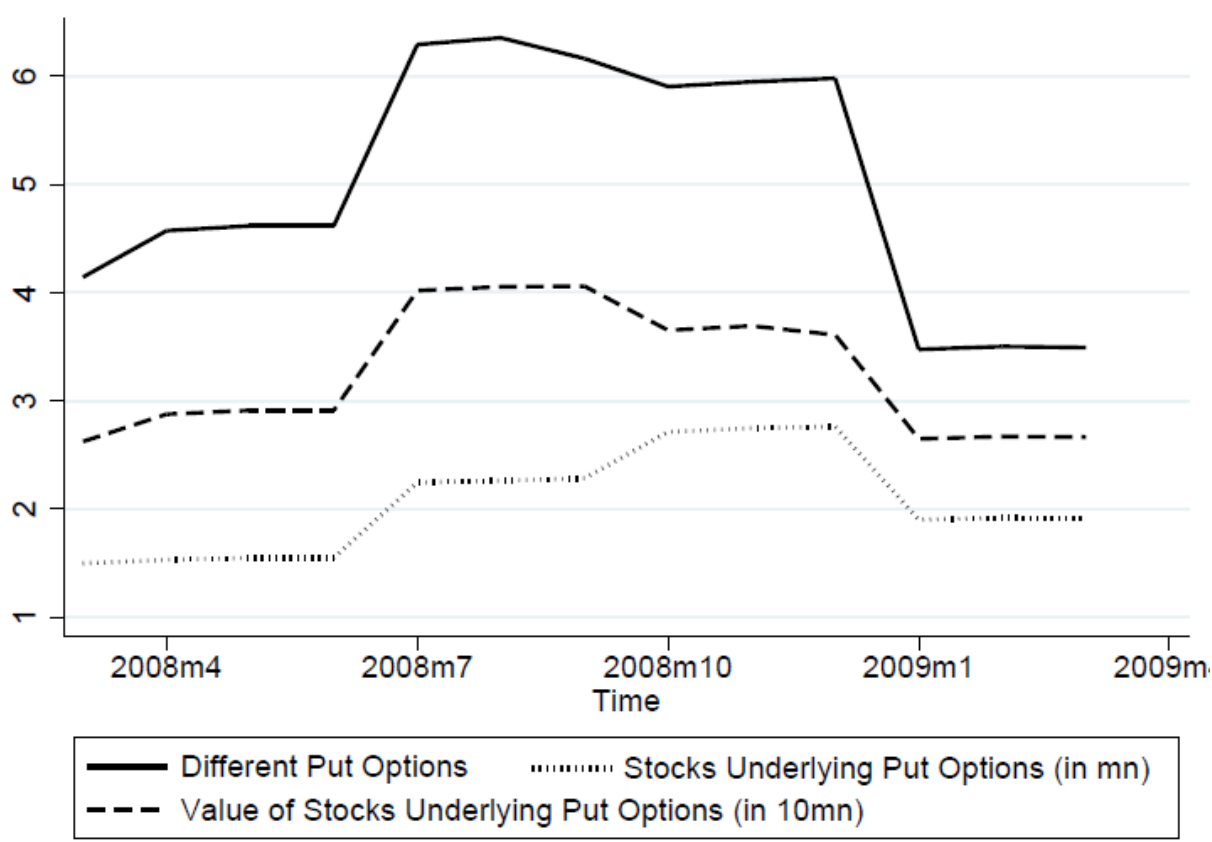




\section{Table 1: Summary Statistics}

This table provides summary statistics for excess returns of hedge funds over the risk-free rate (Panel A), fund characteristics (Panel B), and the TailRisk measure as defined in equation (2) in the main text (Panel C). Summary statistics for the TailRisk measure are calculated as the averages across all funds and across all 24-month periods over which the two measures are estimated. As the risk-free rate we use the one-month T-bill rate. We also display correlations between the aggregate TailRisk measure (computed as the equal-weighted average over all hedge funds) with various risk factors (as defined in the paper) in Panel D. Our sample covers hedge funds from the Union Hedge Fund Database constructed from combining the Eureka, HFR, Morningstar, and Lipper TASS databases. The sample period is from January 1994 to December 2012.

\section{Panel A: Excess Returns}

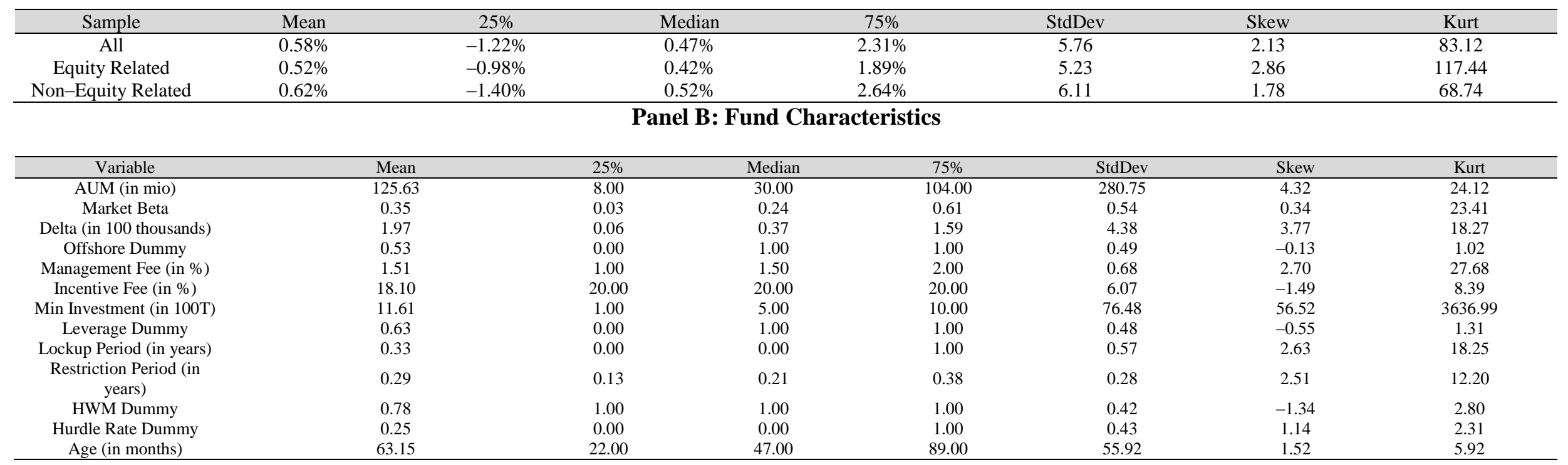


Panel C: TailRisk

\begin{tabular}{|c|c|c|c|c|c|c|c|c|}
\hline Strategy & $\begin{array}{l}\text { Number of } \\
\text { Funds }\end{array}$ & Avg TailRisk & $10 \%$ & $25 \%$ & Median & $75 \%$ & $90 \%$ & Std Dev \\
\hline Emerging Markets & 531 & 0.51 & 0.00 & 0.00 & 0.26 & 0.81 & 1.36 & 0.71 \\
\hline Event Driven & 852 & 0.25 & 0.00 & 0.00 & 0.04 & 0.35 & 0.66 & 0.42 \\
\hline Equity Long-Short & 3736 & 0.41 & 0.00 & 0.00 & 0.21 & 0.64 & 1.10 & 0.58 \\
\hline Equity Long Only & 331 & 0.49 & 0.00 & 0.00 & 0.30 & 0.76 & 1.24 & 0.68 \\
\hline $\begin{array}{c}\text { Equity Market } \\
\text { Neutral }\end{array}$ & 1,265 & 0.12 & 0.00 & 0.00 & 0.00 & 0.10 & 0.39 & 0.29 \\
\hline Short Bias & 66 & 0.07 & 0.00 & 0.00 & 0.00 & 0.00 & 0.12 & 0.27 \\
\hline Sector & 250 & 0.49 & 0.00 & 0.00 & 0.26 & 0.75 & 1.30 & 0.70 \\
\hline Equity Related & 6,281 & 0.38 & 0.00 & 0.00 & 0.12 & 0.58 & 1.06 & 0.58 \\
\hline CTA & 1,094 & 0.17 & 0.00 & 0.00 & 0.00 & 0.00 & 0.65 & 0.50 \\
\hline Global Macro & 599 & 0.23 & 0.00 & 0.00 & 0.00 & 0.29 & 0.77 & 0.49 \\
\hline Multi-Strategy & 1,265 & 0.19 & 0.00 & 0.00 & 0.00 & 0.21 & 0.61 & 0.41 \\
\hline Relative Value & 1,142 & 0.16 & 0.00 & 0.00 & 0.00 & 0.17 & 0.48 & 0.35 \\
\hline Others & 453 & 0.23 & 0.00 & 0.00 & 0.09 & 0.33 & 0.61 & 0.35 \\
\hline Non-Equity Related & 4,553 & 0.19 & 0.00 & 0.00 & 0.00 & 0.20 & 0.61 & 0.43 \\
\hline All & 10,834 & 0.30 & 0.00 & 0.00 & 0.00 & 0.45 & 0.92 & 0.53 \\
\hline
\end{tabular}

Panel D: Correlation between Aggregate TailRisk and Hedge Fund Risk Factors

\begin{tabular}{ccccccc}
\hline & TailRisk & Market & TED Spread & PS Liquidity & Macro Uncertainty & Correlation Risk \\
\hline TailRisk & 1.00 & & & & & \\
Market & -0.03 & 1.00 & & & \\
TED Spread & 0.49 & -0.18 & 1.00 & 1.00 & 1.00 & -0.06 \\
PS Liquidity & -0.04 & 0.25 & -0.18 & -0.06 & 0.16 & 0.01 \\
Macro Uncertainty & -0.16 & 0.00 & 0.13 & -0.25 & 0.12 \\
Correlation Swap & 0.07 & -0.48 & 0.44 & & \\
VIX & 0.09 & -0.39 & & & \\
\hline
\end{tabular}




\section{Table 2: Tail Risk and Hedge Fund Performance}

This table reports the results from the analysis of the relation between TailRisk of hedge funds in month $t$ and their monthly excess returns in month $t+1$. Panel A reports the results from equal-weighted univariate portfolio sorts based on TailRisk in month $t$ and risk-adjusted returns in month $t+1$. In each month, we rank funds into portfolios based on their lagged realized TailRisk and form equally-weighted portfolios at the beginning of each month. The column "Excess Return" reports the average portfolio return in excess of the one-month T-bill rate in the following month. The columns labeled "Car-4-Factor" and "FH-7-Factor" report the monthly alpha using the Carhart (1997) fourfactor model and the Fung and Hsieh (2004) seven-factor model. In Panel B, we regress the return of a portfolio consisting funds in portfolio 1 with the lowest tail risk subtracted from the returns of the funds in portfolio 10 with the highest tail risk, on different risk factors. As risk factors, we use in addition to the factors in the Fung and Hsieh (2004) seven-factor model presented in the first column, the MSCI Emerging Markets factor (MSCI EM), the Pástor and Stambaugh (2003) traded liquidity factor (Traded PS Liquidity), the Fama and French (1993) value factor (HML), Carhart (1997) momentum factor (UMD), and the returns of a long-short hedge funds portfolio with regard to the Bali, Brown, and Caglayan (2014) macroeconomic uncertainty factor (Return Macro), the Buraschi, Kosowski, and Trojani (2014) correlation risk factor (Return CORR), and the VIX (Return VIX). The seven factors in Fung and Hsieh (2004) model include the three trend-following risk factors constructed using portfolios of lookback straddle options on currencies (PTFSFX), commodities (PTFSCOM), and bonds (PTFSBD); two equity-oriented risk factors constructed using excess S\&P 500 index returns (S\&P), and the return difference of Russell 2000 index and S\&P 500 index (SCMLC); two bond-oriented risk factors constructed using 10-year Treasury constant maturity bond yields (BD10RET), and the difference in yields of Moody's Baa bonds and 10-year Treasury constant maturity bonds (BAAMTSY), all yields adjusted for the duration to convert them into returns. Panel C reports the results of Fama and MacBeth (1973) regressions of excess returns in month $t+1$ on TailRisk and different fund characteristics (as defined in the main text) measured in month $t$. Finally, Panel D shows the results of Fama and MacBeth (1973) regressions of future excess returns with different horizons on TailRisk and different fund characteristics measured in month $t$. We use the Newey-West (1987) adjustment with 24 lags to adjust the standard errors for serial correlation in all Fama and MacBeth (1973) regressions. Our sample covers hedge funds from the Union Hedge Fund Database constructed from combining the Eureka, HFR, Morningstar, and Lipper TASS databases. The sample period is from January 1994 to December 2012 . ***, **, and * denotes statistical significance at the $1 \%, 5 \%$, and $10 \%$ level, respectively. 
Panel A: Univariate Portfolio Sorts

\begin{tabular}{|c|c|c|c|c|c|c|c|c|c|c|}
\hline \multirow[b]{2}{*}{ Portfolio } & \multicolumn{4}{|c|}{ All Funds } & \multicolumn{3}{|c|}{ Equity-Related Hedge Funds } & \multicolumn{3}{|c|}{ Non-Equity Related Hedge Funds } \\
\hline & $\begin{array}{c}(1) \\
\text { TailRisk } \\
\end{array}$ & $\begin{array}{c}(2) \\
\text { Excess Return } \\
\end{array}$ & $\begin{array}{c}(3) \\
\text { Car-4-Factor }\end{array}$ & $\begin{array}{c}(4) \\
\text { FH-7-Factor } \\
\end{array}$ & $\begin{array}{c}(5) \\
\text { Excess Return } \\
\end{array}$ & $\begin{array}{c}(6) \\
\text { Car-4-Factor } \\
\end{array}$ & $\begin{array}{c}(7) \\
\text { FH-7-Factor } \\
\end{array}$ & $\begin{array}{c}(8) \\
\text { Excess Return }\end{array}$ & $\begin{array}{c}(9) \\
\text { Car-4-Factor } \\
\end{array}$ & $\begin{array}{c}(10) \\
\text { FH-7-Factor }\end{array}$ \\
\hline 1 (Lowest) & 0.00 & $0.45 \%$ & $0.33 \%$ & $0.36 \%$ & $0.49 \%$ & $0.28 \%$ & $0.34 \%$ & $0.47 \%$ & $0.42 \%$ & $0.42 \%$ \\
\hline 2 & 0.11 & $0.42 \%$ & $0.33 \%$ & $0.34 \%$ & $0.45 \%$ & $0.31 \%$ & $0.36 \%$ & $0.38 \%$ & $0.33 \%$ & $0.32 \%$ \\
\hline 3 & 0.25 & $0.38 \%$ & $0.27 \%$ & $0.28 \%$ & $0.36 \%$ & $0.23 \%$ & $0.28 \%$ & $0.41 \%$ & $0.29 \%$ & $0.28 \%$ \\
\hline 4 & 0.37 & $0.47 \%$ & $0.30 \%$ & $0.31 \%$ & $0.49 \%$ & $0.27 \%$ & $0.31 \%$ & $0.41 \%$ & $0.30 \%$ & $0.30 \%$ \\
\hline 5 & 0.46 & $0.50 \%$ & $0.31 \%$ & $0.31 \%$ & $0.49 \%$ & $0.28 \%$ & $0.30 \%$ & $0.53 \%$ & $0.37 \%$ & $0.37 \%$ \\
\hline 6 & 0.57 & $0.63 \%$ & $0.36 \%$ & $0.39 \%$ & $0.61 \%$ & $0.31 \%$ & $0.35 \%$ & $0.61 \%$ & $0.41 \%$ & $0.42 \%$ \\
\hline 7 & 0.70 & $0.60 \%$ & $0.38 \%$ & $0.40 \%$ & $0.60 \%$ & $0.36 \%$ & $0.39 \%$ & $0.49 \%$ & $0.37 \%$ & $0.36 \%$ \\
\hline 8 & 0.88 & $0.66 \%$ & $0.40 \%$ & $0.43 \%$ & $0.65 \%$ & $0.41 \%$ & $0.42 \%$ & $0.75 \%$ & $0.49 \%$ & $0.53 \%$ \\
\hline 9 & 1.15 & $0.80 \%$ & $0.59 \%$ & $0.59 \%$ & $0.87 \%$ & $0.53 \%$ & $0.52 \%$ & $0.64 \%$ & $0.47 \%$ & $0.48 \%$ \\
\hline 10 (Highest) & 2.01 & $1.01 \%$ & $0.86 \%$ & $0.76 \%$ & $1.13 \%$ & $0.83 \%$ & $0.78 \%$ & $0.64 \%$ & $0.52 \%$ & $0.49 \%$ \\
\hline $10-1$ & 2.01 & $\begin{array}{l}0.56 \% * * \\
(2.02)\end{array}$ & $\begin{array}{l}0.53 \% * * \\
(2.18)\end{array}$ & $\begin{array}{l}0.40 \% * \\
(1.87) \\
\end{array}$ & $\begin{array}{l}0.64 \% * * \\
(2.25)\end{array}$ & $\begin{array}{l}0.55 \% * * * \\
(3.21)\end{array}$ & $\begin{array}{l}0.44 \% * * \\
(2.00)\end{array}$ & $\begin{array}{l}0.17 \% \\
(0.50)\end{array}$ & $\begin{array}{l}0.10 \% \\
(0.26) \\
\end{array}$ & $\begin{array}{l}0.07 \% \\
(0.35)\end{array}$ \\
\hline
\end{tabular}


Table 2: (Continued)

Panel B: Equity-Related Hedge Funds: Additional Factors

\begin{tabular}{|c|c|c|c|c|c|c|c|c|}
\hline & $\begin{array}{c}(1) \\
\text { PF 10-1 }\end{array}$ & $\begin{array}{c}(2) \\
\text { PF } 10-1\end{array}$ & $\begin{array}{c}(3) \\
\text { PF 10-1 }\end{array}$ & $\begin{array}{c}(4) \\
\text { PF 10-1 }\end{array}$ & $\begin{array}{c}(5) \\
\text { PF 10-1 }\end{array}$ & $\begin{array}{c}(6) \\
\text { PF 10-1 }\end{array}$ & $\begin{array}{c}(7) \\
\text { PF 10-1 }\end{array}$ & $\begin{array}{c}(8) \\
\text { PF 10-1 }\end{array}$ \\
\hline S\&P & $\begin{array}{c}0.860 * * * \\
(17.35)\end{array}$ & $\begin{array}{c}0.624 * * * \\
(8.88)\end{array}$ & $\begin{array}{c}0.607 * * * \\
(9.28)\end{array}$ & $\begin{array}{c}0.592 * * * \\
(8.50)\end{array}$ & $\begin{array}{c}0.614 * * * \\
(8.73)\end{array}$ & $\begin{array}{c}0.621 * * * \\
(8.81)\end{array}$ & $\begin{array}{c}0.278^{* * * *} \\
(3.49)\end{array}$ & $\begin{array}{c}0.172 * * \\
(2.22)\end{array}$ \\
\hline SCMLC & $\begin{array}{c}0.282 * * * \\
(4.52)\end{array}$ & $\begin{array}{c}0.196 * * * \\
(3.13)\end{array}$ & $\begin{array}{c}0.156 * * * \\
(2.66)\end{array}$ & $\begin{array}{c}0.220 * * * \\
(3.56)\end{array}$ & $\begin{array}{c}0.192 * * * \\
(3.08)\end{array}$ & $\begin{array}{c}0.195 * * * \\
(3.09)\end{array}$ & $\begin{array}{c}0.0944 \\
(1.63)\end{array}$ & $\begin{array}{c}-0.0524 \\
(-0.88)\end{array}$ \\
\hline BD10RET & $\begin{array}{c}-0.203^{*} \\
(-1.66)\end{array}$ & $\begin{array}{c}-0.194^{*} \\
(-1.67)\end{array}$ & $\begin{array}{l}-0.164 \\
(-1.52)\end{array}$ & $\begin{array}{l}-0.188 \\
(-1.65)\end{array}$ & $\begin{array}{l}-0.191 \\
(-1.65)\end{array}$ & $\begin{array}{c}-0.213^{*} \\
(-1.81)\end{array}$ & $\begin{array}{c}-0.0623 \\
(-0.59)\end{array}$ & $\begin{array}{c}-0.0226 \\
(-0.23)\end{array}$ \\
\hline BAAMTSY & $\begin{array}{c}0.366^{* * * *} \\
(2.99)\end{array}$ & $\begin{array}{c}0.283 * * \\
(2.40)\end{array}$ & $\begin{array}{c}0.364 * * * \\
(3.29)\end{array}$ & $\begin{array}{c}0.268 * * \\
(2.31)\end{array}$ & $\begin{array}{c}0.311 * * * \\
(2.61)\end{array}$ & $\begin{array}{c}0.256^{* *} \\
(2.13)\end{array}$ & $\begin{array}{c}0.0782 \\
(0.72)\end{array}$ & $\begin{array}{l}0.102 \\
(1.01)\end{array}$ \\
\hline PTFSBD & $\begin{array}{c}0.0514 * * * \\
(3.29)\end{array}$ & $\begin{array}{c}0.0570 * * * \\
(3.82)\end{array}$ & $\begin{array}{c}0.0453 * * * \\
(3.22)\end{array}$ & $\begin{array}{c}0.0522 * * * \\
(3.55)\end{array}$ & $\begin{array}{c}0.0580 * * * \\
(3.89)\end{array}$ & $\begin{array}{c}0.0557 * * * \\
(3.65)\end{array}$ & $\begin{array}{c}0.0448 * * * \\
(3.30)\end{array}$ & $\begin{array}{c}0.0533 * * * \\
(4.21)\end{array}$ \\
\hline PTFSFX & $\begin{array}{c}-0.00178 \\
(-0.13)\end{array}$ & $\begin{array}{c}-0.00283 \\
(-0.22)\end{array}$ & $\begin{array}{c}0.000530 \\
(0.05)\end{array}$ & $\begin{array}{c}-0.00232 \\
(-0.19)\end{array}$ & $\begin{array}{c}-0.00413 \\
(-0.33)\end{array}$ & $\begin{array}{c}-0.00311 \\
(-0.24)\end{array}$ & $\begin{array}{c}-0.00442 \\
(-0.39)\end{array}$ & $\begin{array}{c}0.00288 \\
(0.27)\end{array}$ \\
\hline PTFSCOM & $\begin{array}{c}-0.0162 \\
(-0.97)\end{array}$ & $\begin{array}{c}-0.0149 \\
(-0.93)\end{array}$ & $\begin{array}{c}-0.0187 \\
(-1.25)\end{array}$ & $\begin{array}{c}-0.00630 \\
(-0.39)\end{array}$ & $\begin{array}{c}-0.0160 \\
(-1.00)\end{array}$ & $\begin{array}{c}-0.0149 \\
(-0.92)\end{array}$ & $\begin{array}{c}-0.0185 \\
(-1.29)\end{array}$ & $\begin{array}{c}-0.00686 \\
(-0.51)\end{array}$ \\
\hline MSCI EM & & $\begin{array}{c}0.215^{* * * *} \\
(4.54)\end{array}$ & $\begin{array}{c}0.184 * * * \\
(4.15)\end{array}$ & $\begin{array}{c}0.203 * * * \\
(4.36)\end{array}$ & $\begin{array}{c}0.227 * * * \\
(4.73)\end{array}$ & $\begin{array}{c}0.217 * * * \\
(4.56)\end{array}$ & $\begin{array}{c}0.104 * * \\
(2.29)\end{array}$ & $\begin{array}{c}0.0101 \\
(0.22)\end{array}$ \\
\hline HML & & & $\begin{array}{c}-0.321 * * * \\
(-5.60)\end{array}$ & & & & & \\
\hline UMD & & & & $\begin{array}{c}-0.116 * * * \\
(-3.01)\end{array}$ & & & & \\
\hline Traded PS Liquidity & & & & & $\begin{array}{c}-0.0756 \\
(-1.47)\end{array}$ & & & \\
\hline Return Macro & & & & & & $\begin{array}{c}-0.0571 \\
(-1.03)\end{array}$ & & \\
\hline Return CORR & & & & & & & $\begin{array}{c}0.610 * * * \\
(7.11)\end{array}$ & \\
\hline Return VIX & & & & & & & & $\begin{array}{c}0.737 * * * \\
(9.01)\end{array}$ \\
\hline Alpha & $\begin{array}{c}0.437 * * \\
(2.00)\end{array}$ & $\begin{array}{c}0.436 * * \\
(2.06)\end{array}$ & $\begin{array}{c}0.508 * * \\
(2.57)\end{array}$ & $\begin{array}{c}0.498 * * \\
(2.39)\end{array}$ & $\begin{array}{c}0.483 * * \\
(2.26)\end{array}$ & $\begin{array}{c}0.518 * * \\
(2.35)\end{array}$ & $\begin{array}{c}0.356^{*} \\
(1.86)\end{array}$ & $\begin{array}{c}0.543 * * * \\
(3.02)\end{array}$ \\
\hline Observations & 204 & 204 & 204 & 204 & 204 & 204 & 204 & 204 \\
\hline Adjusted $\mathrm{R}^{2}$ & 0.673 & 0.703 & 0.743 & 0.715 & 0.705 & 0.705 & 0.765 & 0.791 \\
\hline
\end{tabular}


Table 2: (Continued)

Panel C: Fama and MacBeth Regressions

\begin{tabular}{|c|c|c|c|c|}
\hline & $\begin{array}{l}\text { (1) } \\
\text { Future Excess } \\
\text { Return }\end{array}$ & $\begin{array}{l}(2) \\
\text { Future Excess } \\
\text { Return }\end{array}$ & $\begin{array}{l}(3) \\
\text { Future Excess } \\
\text { Return }\end{array}$ & $\begin{array}{c}(4) \\
\text { Future Excess } \\
\text { Return }\end{array}$ \\
\hline TailRisk & $\begin{array}{c}0.451 * * \\
(2.01)\end{array}$ & $\begin{array}{c}0.226 * * * \\
(3.37)\end{array}$ & $\begin{array}{c}0.425^{*} \\
(1.85)\end{array}$ & $\begin{array}{c}0.217 * * * \\
(3.20)\end{array}$ \\
\hline Size & & $\begin{array}{c}-0.0857 * * * \\
(-3.39)\end{array}$ & & $\begin{array}{c}-0.0847 * * * \\
(-3.30)\end{array}$ \\
\hline Age & & $\begin{array}{c}-0.000620 \\
(-1.52)\end{array}$ & & $\begin{array}{c}-0.000192 \\
(-0.47)\end{array}$ \\
\hline Past Yearly Return & & $\begin{array}{c}0.0240 * * * \\
(6.10)\end{array}$ & & $\begin{array}{c}0.0233 * * * \\
(9.37)\end{array}$ \\
\hline Standard Deviation & & $\begin{array}{c}0.0370^{*} \\
(1.95)\end{array}$ & & $\begin{array}{c}0.0395 * \\
(1.94)\end{array}$ \\
\hline Skewness & & $\begin{array}{c}0.0336 \\
(0.81)\end{array}$ & & $\begin{array}{c}0.0261 \\
(0.68)\end{array}$ \\
\hline Kurtosis & & $\begin{array}{c}-0.00934 \\
(-0.73)\end{array}$ & & $\begin{array}{c}-0.0149 \\
(-1.21)\end{array}$ \\
\hline VaR & & $\begin{array}{c}0.0110 \\
(0.66)\end{array}$ & & $\begin{array}{c}0.00959 \\
(0.55)\end{array}$ \\
\hline ES & & $\begin{array}{c}0.00284 \\
(0.15)\end{array}$ & & $\begin{array}{c}0.00567 \\
(0.25)\end{array}$ \\
\hline Beta & & $\begin{array}{l}0.105 \\
(0.46)\end{array}$ & & $\begin{array}{c}0.0995 \\
(0.43)\end{array}$ \\
\hline Delta & & $\begin{array}{c}0.0191 * * * * \\
(4.04)\end{array}$ & & $\begin{array}{c}0.0166^{* * * *} \\
(3.16)\end{array}$ \\
\hline Lockup Period & & & $\begin{array}{c}0.0885 * * \\
(2.06)\end{array}$ & $\begin{array}{c}0.0559 * \\
(1.75)\end{array}$ \\
\hline Restriction Period & & & $\begin{array}{c}0.0225 \\
(0.41)\end{array}$ & $\begin{array}{c}0.0592 \\
(1.58)\end{array}$ \\
\hline Min Investment & & & $\begin{array}{c}0.00161 \\
(1.44)\end{array}$ & $\begin{array}{c}0.00199 * * * \\
(2.80)\end{array}$ \\
\hline Leverage & & & $\begin{array}{c}0.00617 \\
(0.13)\end{array}$ & $\begin{array}{c}0.0255 \\
(0.66)\end{array}$ \\
\hline Offshore & & & $\begin{array}{c}-0.0135 \\
(-0.14)\end{array}$ & $\begin{array}{l}0.0253 \\
(0.35)\end{array}$ \\
\hline Management Fee & & & $\begin{array}{c}0.0718 \\
(1.39)\end{array}$ & $\begin{array}{c}0.0393 \\
(1.01)\end{array}$ \\
\hline Incentive Fee & & & $\begin{array}{c}0.00167 \\
(0.47)\end{array}$ & $\begin{array}{c}-0.000103 \\
(-0.04)\end{array}$ \\
\hline Hurdle Rate & & & $\begin{array}{c}0.141 * * * \\
(5.28)\end{array}$ & $\begin{array}{c}0.0961 * * * \\
(4.47)\end{array}$ \\
\hline HWM & & & $\begin{array}{c}0.120^{* *} \\
(2.09)\end{array}$ & $\begin{array}{c}0.0968 * * \\
(2.14)\end{array}$ \\
\hline Constant & $\begin{array}{c}0.426^{* * * *} \\
(3.08)\end{array}$ & $\begin{array}{c}0.615 * * * \\
(4.56)\end{array}$ & $\begin{array}{l}0.108 \\
(0.82)\end{array}$ & $\begin{array}{c}0.360 * * * \\
(2.72)\end{array}$ \\
\hline $\begin{array}{c}\text { Observations } \\
\text { Adjusted } \mathrm{R}^{2} \\
\end{array}$ & $\begin{array}{c}420,329 \\
0.058 \\
\end{array}$ & $\begin{array}{c}287,383 \\
0.212 \\
\end{array}$ & $\begin{array}{c}261,478 \\
0.080 \\
\end{array}$ & $\begin{array}{c}195,170 \\
0.236 \\
\end{array}$ \\
\hline
\end{tabular}


Table 2: (Continued)

Panel D: Predictability of TailRisk on Longer-Term Returns

\begin{tabular}{|c|c|c|c|c|c|}
\hline & $\begin{array}{c}(1) \\
\text { Baseline } \\
\text { Holding Period: } \\
1 \text { month }\end{array}$ & $\begin{array}{c}(2) \\
\text { Excess Return } \\
\text { Holding Period: } \\
2 \text { months }\end{array}$ & $\begin{array}{c}(3) \\
\text { Excess Return } \\
\text { Holding Period: } \\
3 \text { months }\end{array}$ & $\begin{array}{c}(4) \\
\text { Excess Return } \\
\text { Holding Period: } \\
6 \text { months }\end{array}$ & $\begin{array}{c}(5) \\
\text { Excess Return } \\
\text { Holding Period: } \\
12 \text { months }\end{array}$ \\
\hline TailRisk & $\begin{array}{c}0.217 * * * \\
(3.20)\end{array}$ & $\begin{array}{c}0.316^{* *} \\
(2.40)\end{array}$ & $\begin{array}{c}0.387 * * \\
(2.20)\end{array}$ & $\begin{array}{c}0.545^{*} \\
(1.87)\end{array}$ & $\begin{array}{l}0.617 \\
(1.20)\end{array}$ \\
\hline Size & $\begin{array}{c}-0.0847 * * * \\
(-3.30)\end{array}$ & $\begin{array}{c}-0.270 * * * \\
(-3.82)\end{array}$ & $\begin{array}{c}-0.251 * * * \\
(-3.67)\end{array}$ & $\begin{array}{c}-0.488 * * * \\
(-3.73)\end{array}$ & $\begin{array}{c}-0.843 * * * \\
(-3.39)\end{array}$ \\
\hline Age & $\begin{array}{c}-0.000192 \\
(-0.47)\end{array}$ & $\begin{array}{c}0.000866 \\
(0.79)\end{array}$ & $\begin{array}{c}-0.000343 \\
(-0.33)\end{array}$ & $\begin{array}{c}-0.000944 \\
(-0.45)\end{array}$ & $\begin{array}{c}-0.00128 \\
(-0.32)\end{array}$ \\
\hline $\begin{array}{l}\text { Past Yearly } \\
\text { Return }\end{array}$ & $\begin{array}{c}0.0233 * * * \\
(9.37)\end{array}$ & $\begin{array}{c}0.0435 * * * \\
(8.57)\end{array}$ & $\begin{array}{c}0.0633 * * * \\
(8.37)\end{array}$ & $\begin{array}{c}0.0976 * * * \\
(7.89)\end{array}$ & $\begin{array}{c}0.134 * * * \\
(8.61)\end{array}$ \\
\hline Standard & $0.0395^{*}$ & $0.0612^{* *}$ & $0.0842 *$ & $0.104 * *$ & $0.142 * *$ \\
\hline Deviation & (1.94) & (2.14) & (1.91) & $(2.13)$ & $(2.12)$ \\
\hline Skewness & $\begin{array}{c}0.0261 \\
(0.68)\end{array}$ & $\begin{array}{c}0.0953 * * \\
(1.12)\end{array}$ & $\begin{array}{c}0.224^{*} \\
(1.84)\end{array}$ & $\begin{array}{c}0.241^{*} \\
(1.21)\end{array}$ & $\begin{array}{l}0.331 \\
(1.11)\end{array}$ \\
\hline Kurtosis & $\begin{array}{c}-0.0149 \\
(-1.21)\end{array}$ & $\begin{array}{c}0.00557 \\
(0.16)\end{array}$ & $\begin{array}{c}-0.0207 \\
(-0.60)\end{array}$ & $\begin{array}{c}-0.0364 \\
(-0.55)\end{array}$ & $\begin{array}{l}-0.149 \\
(-0.84)\end{array}$ \\
\hline $\mathrm{VaR}$ & $\begin{array}{c}0.00959 \\
(0.55)\end{array}$ & $\begin{array}{c}-0.0202 \\
(-0.53)\end{array}$ & $\begin{array}{c}0.0150 \\
(0.45)\end{array}$ & $\begin{array}{c}0.0542 \\
(0.80)\end{array}$ & $\begin{array}{l}0.106 \\
(1.02)\end{array}$ \\
\hline ES & $\begin{array}{c}0.00567 \\
(0.25)\end{array}$ & $\begin{array}{c}0.00362 \\
(0.07)\end{array}$ & $\begin{array}{c}-0.0481 \\
(-1.27)\end{array}$ & $\begin{array}{c}-0.135^{*} \\
(-1.66)\end{array}$ & $\begin{array}{l}-0.176 \\
(-1.05)\end{array}$ \\
\hline Beta & $\begin{array}{c}0.0995 \\
(0.43)\end{array}$ & $\begin{array}{l}0.619 \\
(0.69)\end{array}$ & $\begin{array}{l}0.626 \\
(0.95)\end{array}$ & $\begin{array}{l}1.410 \\
(1.11)\end{array}$ & $\begin{array}{l}2.548 \\
(1.10)\end{array}$ \\
\hline Delta & $\begin{array}{c}0.0166^{* * * *} \\
(3.16)\end{array}$ & $\begin{array}{l}0.0798^{* * * *} \\
(3.40)\end{array}$ & $\begin{array}{c}0.0482 * * * * \\
(3.64)\end{array}$ & $\begin{array}{c}0.0993 * * * \\
(3.51)\end{array}$ & $\begin{array}{c}0.194 * * * \\
(2.84)\end{array}$ \\
\hline Lockup Period & $\begin{array}{c}0.0559 * \\
(1.75)\end{array}$ & $\begin{array}{c}0.208 * * * \\
(2.63)\end{array}$ & $\begin{array}{c}0.200 * * \\
(2.30)\end{array}$ & $\begin{array}{c}0.442 * * \\
(2.29)\end{array}$ & $\begin{array}{c}1.085 * * * \\
(2.80)\end{array}$ \\
\hline Restriction Period & $\begin{array}{c}0.0592 \\
(1.58)\end{array}$ & $\begin{array}{l}0.159 \\
(1.33)\end{array}$ & $\begin{array}{l}0.151 \\
(1.08)\end{array}$ & $\begin{array}{l}0.332 \\
(1.15)\end{array}$ & $\begin{array}{l}0.645 \\
(1.09)\end{array}$ \\
\hline Min Investment & $\begin{array}{c}0.00199 * * * \\
(2.80)\end{array}$ & $\begin{array}{c}0.00285 \\
(1.29)\end{array}$ & $\begin{array}{l}0.00493 * * \\
(2.51)\end{array}$ & $\begin{array}{l}0.0113 * * * \\
(2.74)\end{array}$ & $\begin{array}{c}0.0257 * * * \\
(2.83)\end{array}$ \\
\hline Leverage & $\begin{array}{l}0.0255 \\
(0.66)\end{array}$ & $\begin{array}{l}0.0578 \\
(0.57)\end{array}$ & $\begin{array}{l}0.132 \\
(1.14)\end{array}$ & $\begin{array}{l}0.162 \\
(0.68)\end{array}$ & $\begin{array}{l}0.218 \\
(0.43)\end{array}$ \\
\hline Offshore & $\begin{array}{c}0.0253 \\
(0.35)\end{array}$ & $\begin{array}{c}0.0592 \\
(0.31)\end{array}$ & $\begin{array}{l}0.0318 \\
(0.15)\end{array}$ & $\begin{array}{l}0.223 \\
(0.50)\end{array}$ & $\begin{array}{l}0.668 \\
(0.78)\end{array}$ \\
\hline Management Fee & $\begin{array}{c}0.0393 \\
(1.01)\end{array}$ & $\begin{array}{l}0.103 \\
(1.02)\end{array}$ & $\begin{array}{l}0.146 \\
(1.36)\end{array}$ & $\begin{array}{l}0.315 \\
(1.44)\end{array}$ & $\begin{array}{l}0.469 \\
(1.09)\end{array}$ \\
\hline Incentive Fee & $\begin{array}{c}-0.000103 \\
(-0.04)\end{array}$ & $\begin{array}{c}-0.00663 \\
(-1.35)\end{array}$ & $\begin{array}{c}0.000613 \\
(0.07)\end{array}$ & $\begin{array}{c}-0.00181 \\
(-0.10)\end{array}$ & $\begin{array}{c}-0.0179 \\
(-0.84)\end{array}$ \\
\hline Hurdle Rate & $\begin{array}{c}0.0961 * * * \\
(4.47)\end{array}$ & $\begin{array}{c}0.174 * \\
(1.69)\end{array}$ & $\begin{array}{c}0.276^{* * * *} \\
(4.71)\end{array}$ & $\begin{array}{c}0.676 * * * \\
(4.37)\end{array}$ & $\begin{array}{c}1.432 * * * \\
(3.05)\end{array}$ \\
\hline HWM & $\begin{array}{c}0.0968 * * \\
(2.14)\end{array}$ & $\begin{array}{l}0.202 \\
(1.46)\end{array}$ & $\begin{array}{c}0.252^{*} \\
(1.78)\end{array}$ & $\begin{array}{c}0.568^{*} \\
(1.89)\end{array}$ & $\begin{array}{c}1.407 * * \\
(2.03)\end{array}$ \\
\hline Constant & $\begin{array}{c}0.360 * * * \\
(2.72)\end{array}$ & $\begin{array}{c}1.090 * * * \\
(2.71)\end{array}$ & $\begin{array}{c}1.173 * * * \\
(3.03)\end{array}$ & $\begin{array}{c}2.097 * * * \\
(2.76)\end{array}$ & $\begin{array}{c}3.868^{* * *} \\
(2.26)\end{array}$ \\
\hline $\begin{array}{l}\text { Observations } \\
\text { Adjusted } \mathrm{R}^{2}\end{array}$ & $\begin{array}{c}195,170 \\
0.236\end{array}$ & $\begin{array}{c}194401 \\
0.256\end{array}$ & $\begin{array}{c}190953 \\
0.257\end{array}$ & $\begin{array}{c}189598 \\
0.251 \\
\end{array}$ & $\begin{array}{c}186512 \\
0.255\end{array}$ \\
\hline
\end{tabular}




\section{Table 3: Tail Risk and Hedge Fund Performance: Robustness Checks}

This table reports the results from robustness checks of the relation between TailRisk of hedge funds in month $t$ and their monthly excess returns in month $t+1$. We investigate the robustness if we (i) change the estimation horizon of the TailRisk measure to 3 and 4 years, respectively, (ii) compute TailRisk using different cut-off values of $10 \%$ and $20 \%$ to define worst returns, (iii) use VaR instead of ES in the computation of TailRisk, (iv) apply a value-weighted sorting procedure instead of an equal-weighted sorting procedure, and (v) use daily returns instead of monthly returns to estimate TailRisk for a subsample of funds that report daily returns to Bloomberg. Panel A displays the results of from the same univariate portfolio sorts as in Column 7, Panel A, Table 2 using these alternative definitions of TailRisk. Panel B reports the results of Fama and MacBeth (1973) regression (4) of Panel D in Table 2 of future excess returns in month $t+1$ on the same alternative TailRisk definitions and different fund characteristics measured in month $t$. The baseline specification in Column (1) is to estimate TailRisk as in Table 2 with two years of monthly returns with a cut-off percentile of $5 \%$ of the return observations. Our sample covers hedge funds from the Union Hedge Fund Database constructed from combining the Eureka, HFR, Morningstar, and Lipper TASS databases. The sample period is from January 1994 to December 2012.***,**, and * denotes statistical significance at the 1\%, 5\%, and 10\% level, respectively. We only display the results of the relation between TailRisk and future excess returns (control variables are included but suppressed in the table).

Panel A: Equity-Related Hedge Funds: Portfolio Sorts

\begin{tabular}{|c|c|c|c|c|c|c|c|c|}
\hline & $\begin{array}{c}\text { (1) } \\
\text { Equity- } \\
\text { Related } \\
\text { Baseline }\end{array}$ & $\begin{array}{c}\text { (2) } \\
\text { Equity- } \\
\text { Related } \\
\text { Horizon } \\
3 y \\
\end{array}$ & $\begin{array}{c}\text { (3) } \\
\text { Equity- } \\
\text { Related } \\
\text { Horizon } \\
4 y \\
\end{array}$ & $\begin{array}{c}\text { (4) } \\
\text { Equity- } \\
\text { Related } \\
\text { Cut-Off } \\
10 \%\end{array}$ & $\begin{array}{c}\text { (5) } \\
\text { Equity- } \\
\text { Related } \\
\text { Cut-Off } \\
20 \% \\
\end{array}$ & $\begin{array}{c}\text { (6) } \\
\text { Equity- } \\
\text { Related } \\
\text { VaR }\end{array}$ & $\begin{array}{c}\text { (7) } \\
\text { Equity- } \\
\text { Related } \\
\text { Value- } \\
\text { Weighted }\end{array}$ & $\begin{array}{c}(8) \\
\text { Bloomberg } \\
\text { Daily } \\
\text { Returns }\end{array}$ \\
\hline $\begin{array}{c}\text { TailRisk } \\
10-1\end{array}$ & $\begin{array}{c}0.44 \% * * \\
(2.00) \\
\end{array}$ & $\begin{array}{c}0.38 \% * * \\
(2.06)\end{array}$ & $\begin{array}{c}0.34 \% * \\
(1.81) \\
\end{array}$ & $\begin{array}{c}0.40 \% * * \\
(1.98)\end{array}$ & $\begin{array}{c}0.35 \% * \\
(1.83) \\
\end{array}$ & $\begin{array}{c}0.36 \% * \\
(1.83) \\
\end{array}$ & $\begin{array}{c}0.30 \% * \\
(1.82) \\
\end{array}$ & $\begin{array}{c}0.43 \% * * \\
(2.32)\end{array}$ \\
\hline \multicolumn{9}{|c|}{ Panel B: Fama-MacBeth Regressions } \\
\hline & \multicolumn{2}{|c|}{$\begin{array}{c}\text { (1) } \\
\text { Equity- } \\
\text { Related } \\
\text { Baseline }\end{array}$} & $\begin{array}{c}(2) \\
\text { Equity- } \\
\text { Related } \\
\text { Horizon } \\
3 y\end{array}$ & $\begin{array}{c}(3) \\
\text { Equity- } \\
\text { Related } \\
\text { Horizon } \\
4 y\end{array}$ & $\begin{array}{r}( \\
\text { Equ } \\
\text { Rel } \\
\text { Cut } \\
10\end{array}$ & & $\begin{array}{l}\quad(5) \\
\text { Equity- } \\
\text { Related } \\
\text { Cut-Off } \\
20 \% \\
\end{array}$ & $\begin{array}{c}\text { (6) } \\
\text { Equity- } \\
\text { Related } \\
\text { VaR }\end{array}$ \\
\hline TailRisk & \multicolumn{2}{|c|}{$\begin{array}{c}0.217 * * * \\
(3.20)\end{array}$} & $\begin{array}{c}0.202 * * * \\
(2.97)\end{array}$ & $\begin{array}{l}0.156 * * \\
(2.31)\end{array}$ & \multicolumn{2}{|c|}{$\begin{array}{c}0.187 * * * \\
(3.01)\end{array}$} & $\begin{array}{l}0.167 * * \\
(2.21)\end{array}$ & $\begin{array}{l}0.201 * * \\
(2.43)\end{array}$ \\
\hline Adjusted $\mathrm{R}^{2}$ & \multicolumn{2}{|c|}{0.236} & 0.234 & 0.233 & \multicolumn{2}{|c|}{0.234} & 0.234 & 0.235 \\
\hline
\end{tabular}




\section{Table 4: Tail Risk and Fund Characteristics}

This table reports the results of Fama and MacBeth (1973) regressions of TailRisk in month $t+1$ on fund characteristics in month $t$. For fund characteristics, we include a fund's age, size, delta of the incentive fee contract, past yearly return, standard deviation (estimated over the previous 24 months), the length of a fund's lockup and restriction period (in months), minimum investment amount (in 100 thousands), indicator variables that equal one if the fund employs leverage and is an offshore fund, respectively, and zero otherwise, a fund's management and incentive fee (in \%), and indicator variables that equal one if the fund has a hurdle rate and a high water mark, respectively, and zero otherwise. Our sample covers hedge funds from the Union Hedge Fund Database constructed from combining the Eureka, HFR, Morningstar, and Lipper TASS databases. The sample period is from January 1994 to December 2012. We use the Newey-West (1987) adjustment with 24 lags to adjust the standard errors for serial correlation. $* * *, * *$, and $*$ denotes statistical significance at the $1 \%, 5 \%$, and $10 \%$ level, respectively.

\begin{tabular}{|c|c|c|c|}
\hline & $\begin{array}{c}(1) \\
\text { TailRisk }\end{array}$ & $\begin{array}{c}(2) \\
\text { TailRisk }\end{array}$ & $\begin{array}{c}(3) \\
\text { TailRisk }\end{array}$ \\
\hline Age & $\begin{array}{c}0.000336 * * \\
(2.60)\end{array}$ & & $\begin{array}{c}0.000168 \\
(1.12)\end{array}$ \\
\hline Size & $\begin{array}{c}-0.000282 \\
(-0.11)\end{array}$ & & $\begin{array}{c}-0.000951 \\
(-0.26)\end{array}$ \\
\hline Delta & $\begin{array}{c}0.00280 * * \\
(2.04)\end{array}$ & & $\begin{array}{c}0.00619 * * \\
(2.60)\end{array}$ \\
\hline Past Yearly Return & $\begin{array}{c}-0.00333 * * * \\
(-3.17)\end{array}$ & & $\begin{array}{c}-0.00310 * * * \\
(-2.82)\end{array}$ \\
\hline Standard Deviation & $\begin{array}{c}0.0809 * * * \\
(8.96)\end{array}$ & & $\begin{array}{c}0.0788 * * * \\
(8.33)\end{array}$ \\
\hline Lockup Period & & $\begin{array}{l}0.0410 * * * \\
(5.17)\end{array}$ & $\begin{array}{c}0.0131 * * \\
(2.01)\end{array}$ \\
\hline Restriction Period & & $\begin{array}{c}-0.0000101 \\
(-0.00)\end{array}$ & $\begin{array}{c}-0.0000101 \\
(-0.00)\end{array}$ \\
\hline Min Investment & & $\begin{array}{c}-0.00219 \\
(-1.44)\end{array}$ & $\begin{array}{c}-0.000923 \\
(-1.23)\end{array}$ \\
\hline Leverage & & $\begin{array}{l}0.0187 \\
(1.45)\end{array}$ & $\begin{array}{c}0.0287 * * \\
(2.45)\end{array}$ \\
\hline Offshore & & $\begin{array}{c}-0.0286 \\
(-1.15)\end{array}$ & $\begin{array}{c}-0.0308 \\
(-1.30)\end{array}$ \\
\hline Management Fee & & $\begin{array}{c}-0.00394 \\
(-0.55)\end{array}$ & $\begin{array}{c}-0.0101 \\
(-1.14)\end{array}$ \\
\hline Incentive Fee & & $\begin{array}{c}-0.00477 * * * \\
(-3.50)\end{array}$ & $\begin{array}{c}-0.00407 \\
(-1.38)\end{array}$ \\
\hline Hurdle Rate & & $\begin{array}{c}-0.0211 \\
(-1.63)\end{array}$ & $\begin{array}{c}-0.0267 \\
(-1.08)\end{array}$ \\
\hline HWM & & $\begin{array}{l}0.0185 \\
(1.39)\end{array}$ & $\begin{array}{c}0.0142 \\
(1.28)\end{array}$ \\
\hline Constant & $\begin{array}{c}-0.00197 \\
(-0.11)\end{array}$ & $\begin{array}{c}0.485 * * * \\
(9.49)\end{array}$ & $\begin{array}{c}0.137 * * * \\
(4.40)\end{array}$ \\
\hline $\begin{array}{l}\text { Observations } \\
\text { Adjusted } \mathrm{R}^{2}\end{array}$ & $\begin{array}{c}287301 \\
0.302\end{array}$ & $\begin{array}{c}265145 \\
0.023\end{array}$ & $\begin{array}{c}195108 \\
0.312\end{array}$ \\
\hline
\end{tabular}




\section{Table 5: Tail Risk and Funding Liquidity: Evidence from Lehman Brothers connected Hedge Funds}

Panel A of this table reports the results of a mean comparison test between the TailRisk for equity-related hedge funds with Lehman Brothers as a prime broker and TailRisk for a matched sample (matched both on propensity scores as well as based on the requirement that matched funds belong to the same hedge fund style category as well as the same TailRisk, size, and monthly excess returns decile in August 2007) in the periods from September 2007 to August 2008 (Pre-Crisis), September 2008 to August 2009 (Crisis), and September 2009 to August 2010 (Post-Crisis). Panel B present the results from the following diff-in-diff regression:

$$
\Delta \text { TailRisk }_{i, t}=\alpha+\beta_{1} \Delta_{\text {Postcrisis-Crisis }}+\beta_{2} \Delta_{\text {Crisis-Precrisis }} \times \text { Lehman }+\beta_{3} \Delta_{\text {Postcrisis-Crisis }} \times \text { Lehman }+\kappa X_{i, t-1}+\varepsilon_{i, t}
$$

where $\Delta$ TailRisk $k_{i, t}$ denotes the change in tail risk for hedge fund $i$ between the pre-Lehman crisis and the crisis period, or between the crisis and the postcrisis period, respectively. $\Delta_{\text {Crisis-precrisis }}$ and $\Delta_{\text {Posterisis-crisis }}$ are indicator variables for the period between Crisis and Pre-Crisis, and Post-Crisis and Crisis, respectively, where the respective periods are defined as in Panel A. Lehman is an indicator variable that takes on the value one if a fund has a prime brokerage relation with Lehman Brothers, and zero otherwise. $x_{i, t-1}$ is a vector of fund-specific control variables that includes age, size, delta, returns over the last one year, standard deviation estimated over the previous year, lockup period, restriction period, minimum investment, management fee, incentive fee, and indicator variables whether the fund employs leverage, is an offshore fund, uses a hurdle rate, and uses a high water mark, all measured at time $t-1$. We estimate TailRisk based on an estimation period of 12 months and cluster standard errors by fund. ***, **, and * denotes statistical significance at the $1 \%$, $5 \%$, and $10 \%$ level, respectively.

Panel A: TailRisk: Mean Comparison Tests

\begin{tabular}{|c|c|c|c|c|c|c|c|c|}
\hline \multicolumn{3}{|c|}{ Period 1: September 2007 - August 2008} & \multicolumn{3}{|c|}{ Period 2: September 2008 - August 2009} & \multicolumn{3}{|c|}{ Period 3: September 2009 - August 2010} \\
\hline $\begin{array}{l}\text { Lehman Hedge } \\
\text { Funds }\end{array}$ & $\begin{array}{l}\text { Matched Sample } \\
\text { Non-connected }\end{array}$ & Difference & $\begin{array}{l}\text { Lehman Hedge } \\
\text { Funds }\end{array}$ & $\begin{array}{l}\text { Matched Sample } \\
\text { Non-connected }\end{array}$ & Difference & $\begin{array}{l}\text { Lehman Hedge } \\
\text { Funds }\end{array}$ & $\begin{array}{l}\text { Matched Sample } \\
\text { Non-connected }\end{array}$ & Difference \\
\hline \multicolumn{9}{|c|}{ Match: Propensity Score Model } \\
\hline 0.39 & 0.45 & $\begin{array}{l}-0.06 \\
(-0.56)\end{array}$ & 0.82 & 0.57 & $\begin{array}{c}0.25^{* *} \\
(2.01)\end{array}$ & 0.13 & 0.16 & $\begin{array}{l}-0.03 \\
(-0.48)\end{array}$ \\
\hline \multicolumn{9}{|c|}{ Match: Style, TailRisk, Size, and Returns in August 2007} \\
\hline 0.39 & 0.44 & $\begin{array}{l}-0.05 \\
(-0.39)\end{array}$ & 0.82 & 0.55 & $\begin{array}{c}0.27 * * \\
(2.25)\end{array}$ & 0.13 & 0.15 & $\begin{array}{l}-0.02 \\
(-0.39)\end{array}$ \\
\hline
\end{tabular}


Table 5: (Continued)

Panel B: Diff-in-Diff Analysis

\begin{tabular}{|c|c|c|c|c|}
\hline & \multicolumn{2}{|c|}{$\begin{array}{c}\text { Match: } \\
\text { Propensity Score Model }\end{array}$} & \multicolumn{2}{|c|}{$\begin{array}{c}\text { Match: } \\
\text { Style, TailRisk, Size, and Returns }\end{array}$} \\
\hline & (1) & $(2)$ & (3) & $(4)$ \\
\hline & TailRisk & TailRisk & TailRisk & TailRisk \\
\hline & Change & Change & Change & Change \\
\hline & $-0.553 * * *$ & $-0.516 * * *$ & $-0.575 * * *$ & $-0.586 * * *$ \\
\hline$\Delta_{\text {Postcrisis-Crisis }}$ & $(-5.71)$ & $(-4.11)$ & $(-6.10)$ & $(-5.78)$ \\
\hline \multirow{2}{*}{$\Delta_{\text {Crisis-Precrisis }} \times$ Lehman } & $0.321 * *$ & $0.272 *$ & $0.351 * *$ & $0.252 *$ \\
\hline & $(2.20)$ & $(1.85)$ & $(2.26)$ & $(1.90)$ \\
\hline \multirow{2}{*}{$\Delta_{\text {Postcrisis-Crisis }} \times$ Lehman } & $-0.253^{* *}$ & $-0.228 *$ & $-0.281 * *$ & $-0.221 *$ \\
\hline & $(-2.02)$ & $(-1.81)$ & $(-2.22)$ & $(-1.85)$ \\
\hline \multirow[t]{2}{*}{ Age } & & -0.003 & & -0.000 \\
\hline & & $(-1.15)$ & & $(-0.11)$ \\
\hline \multirow[t]{2}{*}{ Size } & & 0.006 & & 0.013 \\
\hline & & $(1.04)$ & & $(1.21)$ \\
\hline \multirow[t]{2}{*}{ Delta } & & -0.211 & & -0.149 \\
\hline & & $(-1.31)$ & & $(-1.21)$ \\
\hline \multirow[t]{2}{*}{ Past Yearly Return } & & -0.034 & & $-0.091 * *$ \\
\hline & & $(-1.13)$ & & $(-2.13)$ \\
\hline \multirow[t]{2}{*}{ Standard Deviation } & & 0.076 & & -0.036 \\
\hline & & $(0.32)$ & & $(-0.05)$ \\
\hline \multirow[t]{2}{*}{ Lockup Period } & & -0.0004 & & -0.0024 \\
\hline & & $(-0.02)$ & & $(-0.71)$ \\
\hline \multirow[t]{2}{*}{ Restriction Period } & & -0.048 & & -0.093 \\
\hline & & $(-0.34)$ & & $(-0.93)$ \\
\hline \multirow[t]{2}{*}{ Min Investment } & & 0.023 & & $0.099 *$ \\
\hline & & $(0.89)$ & & (1.89) \\
\hline \multirow[t]{2}{*}{ Leverage } & & $0.077 * *$ & & $0.078 * *$ \\
\hline & & $(2.15)$ & & $(2.00)$ \\
\hline \multirow[t]{2}{*}{ Offshore } & & -0.021 & & 0.052 \\
\hline & & $(-0.56)$ & & $(1.46)$ \\
\hline \multirow[t]{2}{*}{ Management Fee } & & 0.003 & & 0.007 \\
\hline & & $(0.14)$ & & $(0.64)$ \\
\hline \multirow[t]{2}{*}{ Incentive Fee } & & 0.008 & & $0.034 *$ \\
\hline & & $(1.12)$ & & (1.88) \\
\hline \multirow[t]{2}{*}{ Hurdle Rate } & & 0.098 & & 0.018 \\
\hline & & $(1.24)$ & & $(0.83)$ \\
\hline \multirow[t]{2}{*}{ HWM } & & -0.099 & & -0.059 \\
\hline & & $(-1.56)$ & & $(-0.96)$ \\
\hline \multirow[t]{2}{*}{ Constant } & $0.210 * * *$ & $0.415 * * *$ & $0.214 * * *$ & $0.447 * * *$ \\
\hline & $(8.45)$ & $(3.26)$ & $(7.75)$ & $(3.51)$ \\
\hline Observations & 2627 & 2049 & 2627 & 2049 \\
\hline Adjusted $\mathrm{R}^{2}$ & 0.180 & 0.312 & 0.180 & 0.312 \\
\hline
\end{tabular}




\section{Table 6: Tail Risk and Portfolio Strategies}

This table reports the results of Fama and MacBeth (1973) regressions of TailRisk in month $t$ on a hedge fund's sensitivity, $\beta$, to different risk factors. As risk factors, we use the Agarwal and Naik (2004) out-of-the-money (OTM) put and call option factors (OTM Put and OTM Call), the Chabi-Yo, Ruenzi, and Weigert (2015) high minus low equity LTD-risk factor (LTD-RISK), the Fung and Hsieh (2004) trend-following factors for bonds, currencies, commodities, interest rates, and equities (PTFSB, PTFSFX, PTFSCOM, PTFSIR, and PTFSSTK), the Pástor and Stambaugh (2003) liquidity risk factor (Liquidity), and returns of a long-short hedge fund portfolio with regard to the Bali, Brown and Caglayan (2014) macroeconomic uncertainty factor (Macro), to the Buraschi, Kosowski, and Trojani (2014) correlation risk factor (Correlation), and to the CBOE VIX index (VIX). We estimate a fund's sensitivity to the respective factor based on a rolling window of 24 monthly returns. Our sample covers hedge funds from the Union Hedge Fund Database constructed from combining the Eureka, HFR, Morningstar, and Lipper TASS databases. The sample period is from January 1994 to December 2012. We use the Newey-West (1987) adjustment with 24 lags and the Shanken (1992) correction to adjust the standard errors for serial correlation and the errors-in-variables problem, respectively. $* * *, * *$, and $*$ denotes statistical significance at the $1 \%, 5 \%$, and $10 \%$ level, respectively.

\begin{tabular}{|c|c|c|c|c|}
\hline & $\begin{array}{c}(1) \\
\text { TailRisk } \\
\end{array}$ & $\begin{array}{c}(2) \\
\text { TailRisk } \\
\end{array}$ & $\begin{array}{c}\text { (3) } \\
\text { TailRisk } \\
\end{array}$ & $\begin{array}{c}(4) \\
\text { TailRisk } \\
\end{array}$ \\
\hline$\beta_{\text {OTM Put }}$ & $\begin{array}{c}-12.46^{* * * *} \\
(-3.63)\end{array}$ & & $\begin{array}{c}-11.85^{* * *} * \\
(-4.76)\end{array}$ & $\begin{array}{c}-9.895 * * \\
(-2.50)\end{array}$ \\
\hline$\beta_{L T D-R I S K}$ & & $\begin{array}{c}0.630^{* * * *} \\
(10.31)\end{array}$ & $\begin{array}{c}0.204 * * * \\
(2.68)\end{array}$ & $\begin{array}{c}0.178^{* * *} \\
(2.21)\end{array}$ \\
\hline$\beta_{\text {отм Call }}$ & & & & $\begin{array}{l}-2.318 \\
(-1.34)\end{array}$ \\
\hline$\beta_{P T F S B}$ & & & & $\begin{array}{l}0.397 \\
(1.11)\end{array}$ \\
\hline$\beta_{P T F S F X}$ & & & & $\begin{array}{l}-0.233 \\
(-0.42)\end{array}$ \\
\hline$\beta_{P T F S C O M}$ & & & & $\begin{array}{l}-0.114 \\
(-0.54)\end{array}$ \\
\hline$\beta_{\text {PTFSIR }}$ & & & & $\begin{array}{l}-0.0447 \\
(-0.16)\end{array}$ \\
\hline$\beta_{\text {PTFSSTK }}$ & & & & $\begin{array}{l}-0.467 \\
(-1.53)\end{array}$ \\
\hline$\beta_{\text {Liquidity }}$ & & & & $\begin{array}{l}-0.0483 \\
(-0.58)\end{array}$ \\
\hline$\beta_{\text {Macro }}$ & & & & $\begin{array}{c}-0.000230 \\
(-0.02)\end{array}$ \\
\hline$\beta_{\text {Correlation }}$ & & & & $\begin{array}{c}0.569^{* *} \\
(2.15)\end{array}$ \\
\hline$\beta_{V I X}$ & & & & $\begin{array}{l}0.284 \\
(1.54)\end{array}$ \\
\hline Constant & $\begin{array}{c}0.0644^{* * * *} \\
(3.98)\end{array}$ & $\begin{array}{c}0.134 * * * * \\
(4.86)\end{array}$ & $\begin{array}{c}0.0579 * * * \\
(4.46)\end{array}$ & $\begin{array}{l}0.0559^{* * * *} \\
\quad(6.11)\end{array}$ \\
\hline Observations & 424334 & 422734 & 422734 & 422712 \\
\hline Adjusted $\mathrm{R}^{2}$ & 0.411 & 0.357 & 0.446 & 0.582 \\
\hline
\end{tabular}




\section{Table 7: Returns-based Tail risk versus Stock-Holdings-based tail risk}

This table reports the results of Fama and MacBeth (1973) regressions of returns-based TailRisk of hedge fund firm $i$ in month $t$ on hedge fund firm $i$ 's Equity Tail Risk in month $t$ controlling for different risk and firm characteristics. As control variables, we include a hedge fund firm's return standard deviation, skewness, kurtosis, ES, beta, downbeta, upbeta, liquidity (as proxied by the Amihud illiquidity ratio), size, book-to-market, and past yearly return. All firm characteristics except liquidity, size, book-to-market, and past yearly return (which are measured at the end of last month) are estimated based on a rolling window of 24 monthly returns of fund firm $i$. In regression (5), we interact Equity Tail Risk with (long-only) leverage defined as a hedge fund firm $i$ 's market capitalization of long equity holdings divided by hedge fund firm i's total assets under management. Our sample covers hedge fund firms from the Union Hedge Fund Database constructed from combining the Eureka, HFR, Morningstar, and Lipper TASS databases who report 13F long equity holdings to the SEC. The sample period is from January 1994 to December 2012. We use the NeweyWest (1987) adjustment with 24 lags to adjust the standard errors for serial correlation. ***, **, and * denotes statistical significance at the $1 \%, 5 \%$, and $10 \%$ level, respectively.

\begin{tabular}{|c|c|c|c|c|c|}
\hline $\begin{array}{c}\text { Stock } \\
\text { Holdings-Based } \\
\text { Variables }\end{array}$ & $\begin{array}{c}(1) \\
\text { TailRisk } \\
\text { (Firm } \\
\text { Level) }\end{array}$ & $\begin{array}{c}(2) \\
\text { TailRisk } \\
\text { (Firm Level) }\end{array}$ & $\begin{array}{c}(3) \\
\text { TailRisk } \\
\text { (Firm Level) }\end{array}$ & $\begin{array}{c}(4) \\
\text { TailRisk } \\
\text { (Firm Level) }\end{array}$ & $\begin{array}{c}(5) \\
\text { TailRisk } \\
\text { (Firm Level) }\end{array}$ \\
\hline Equity Tail Risk & $\begin{array}{c}0.145^{* * * *} \\
(14.97)\end{array}$ & $\begin{array}{c}0.0923 * * * \\
(5.03)\end{array}$ & $\begin{array}{c}0.0918 * * * \\
(4.91)\end{array}$ & $\begin{array}{c}0.0793 * * * \\
(3.69)\end{array}$ & $\begin{array}{c}0.0590 * * * \\
(2.93)\end{array}$ \\
\hline $\begin{array}{c}\text { Equity Tail Risk } \\
\text { x Leverage }\end{array}$ & & & & & $\begin{array}{c}0.0127 * * \\
(2.02)\end{array}$ \\
\hline Standard & & -0.0000680 & -0.00133 & -0.00624 & -0.00939 \\
\hline Deviation & & $(-0.01)$ & $(-0.10)$ & $(-0.38)$ & $(-0.57)$ \\
\hline Skewness & & $\begin{array}{c}0.00969 \\
(0.47)\end{array}$ & $\begin{array}{c}0.0105 \\
(0.48)\end{array}$ & $\begin{array}{c}0.00563 \\
(0.28)\end{array}$ & $\begin{array}{c}0.0136 \\
(0.73)\end{array}$ \\
\hline Kurtosis & & $\begin{array}{c}-0.00411 \\
(-0.54)\end{array}$ & $\begin{array}{c}-0.00517 \\
(-0.69)\end{array}$ & $\begin{array}{c}-0.00699 \\
(-0.78)\end{array}$ & $\begin{array}{c}-0.00613 \\
(-0.66)\end{array}$ \\
\hline ES & & $\begin{array}{c}-0.0123 \\
(-1.48)\end{array}$ & $\begin{array}{c}-0.0135 \\
(-1.48)\end{array}$ & $\begin{array}{c}-0.0169 \\
(-1.45)\end{array}$ & $\begin{array}{c}-0.0190 \\
(-1.61)\end{array}$ \\
\hline Beta & & $\begin{array}{c}0.157 * * * \\
(3.02)\end{array}$ & & & \\
\hline Up Beta & & & $\begin{array}{l}0.0113 \\
(0.25)\end{array}$ & $\begin{array}{c}-0.00915 \\
(-0.15)\end{array}$ & $\begin{array}{c}0.00637 \\
(0.12)\end{array}$ \\
\hline Down Beta & & & $\begin{array}{l}0.122 * \\
(1.86)\end{array}$ & $\begin{array}{c}0.108^{*} \\
(1.94)\end{array}$ & $\begin{array}{c}0.0821 \\
(1.29)\end{array}$ \\
\hline Liquidity & & & & $\begin{array}{c}-0.0391 \\
(-0.88)\end{array}$ & $\begin{array}{c}-0.0288 \\
(-0.70)\end{array}$ \\
\hline Size & & & & $\begin{array}{c}0.00439 \\
(0.64)\end{array}$ & $\begin{array}{c}0.00297 \\
(0.49)\end{array}$ \\
\hline Book-to-market & & & & $\begin{array}{l}-0.373 \\
(-1.56)\end{array}$ & $\begin{array}{l}-0.347 \\
(-1.62)\end{array}$ \\
\hline $\begin{array}{l}\text { Past Yearly } \\
\text { Return }\end{array}$ & & & & $\begin{array}{c}-0.00279 \\
(-1.42)\end{array}$ & $\begin{array}{c}-0.00264 \\
(-1.36)\end{array}$ \\
\hline Constant & $\begin{array}{c}0.206 * * * \\
(7.67)\end{array}$ & $\begin{array}{c}0.00190 \\
(0.03)\end{array}$ & $\begin{array}{c}0.0270 \\
(0.45)\end{array}$ & $\begin{array}{l}0.0293 \\
(0.31)\end{array}$ & $\begin{array}{c}0.0468 \\
(0.56)\end{array}$ \\
\hline $\begin{array}{c}\text { Observations } \\
\text { Adjusted } \mathrm{R}^{2}\end{array}$ & $\begin{array}{l}42353 \\
0.051 \\
\end{array}$ & $\begin{array}{l}41896 \\
0.114 \\
\end{array}$ & $\begin{array}{l}41896 \\
0.121 \\
\end{array}$ & $\begin{array}{l}39708 \\
0.153 \\
\end{array}$ & $\begin{array}{l}39695 \\
0.169 \\
\end{array}$ \\
\hline
\end{tabular}




\section{Table 8: Returns-based Tail risk and Option Holdings}

This table reports the results of Fama and MacBeth (1973) regressions of returns-based TailRisk of hedge fund firm $i$ in month $t$ on hedge fund firm $i$ 's long positions in call and put options in month $t$. We compute a hedge fund firm $i$ 's number of different stocks on which call positions are held (Number of different call positions), number of different stocks on which put positions are held (Number of different put positions), the number of equity shares underlying the call positions (Number of equity shares underlying the call positions, in millions), the number of equity shares underlying the put positions (Number of equity shares underlying the put positions, in millions), the value of equity shares underlying the call positions (Value of equity shares underlying the call positions, in \$ millions), and the value of equity shares underlying the put positions (Value of equity shares underlying the put positions, in millions) Our sample covers hedge fund firms from the Union Hedge Fund Database constructed from combining the Eureka, HFR, Morningstar, and Lipper TASS databases who report long call and put positions to the SEC in their 13F filings. The sample period is from April 1999 to December 2012. We use the Newey-West (1987) adjustment with 24 lags to adjust the standard errors for serial correlation. $* * *, * *$, and $*$ denotes statistical significance at the $1 \%, 5 \%$, and $10 \%$ level, respectively.

\begin{tabular}{|c|c|c|c|c|}
\hline $\begin{array}{c}\text { Derivatives Holdings-Based } \\
\text { Variables }\end{array}$ & $\begin{array}{c}(1) \\
\text { TailRisk } \\
\text { (Firm Level) } \\
\end{array}$ & $\begin{array}{c}(2) \\
\text { TailRisk } \\
\text { (Firm Level) }\end{array}$ & $\begin{array}{c}(3) \\
\text { TailRisk } \\
\text { (Firm Level) }\end{array}$ & $\begin{array}{c}(4) \\
\text { TailRisk } \\
\text { (Firm Level) } \\
\end{array}$ \\
\hline $\begin{array}{l}\text { Number of different call } \\
\text { positions }\end{array}$ & $\begin{array}{l}0.000184 \\
(0.21)\end{array}$ & & & $\begin{array}{l}0.000654 \\
(0.40)\end{array}$ \\
\hline $\begin{array}{l}\text { Number of different put } \\
\text { positions }\end{array}$ & $\begin{array}{c}-0.000988 \\
(-1.33)\end{array}$ & & & $\begin{array}{c}-0.00586 * * \\
(-2.32)\end{array}$ \\
\hline $\begin{array}{l}\text { Number of equity shares } \\
\text { underlying the call positions }\end{array}$ & & $\begin{array}{l}0.00282 \\
(0.52)\end{array}$ & & $\begin{array}{c}0.00405 \\
(1.12)\end{array}$ \\
\hline $\begin{array}{l}\text { Number of equity shares } \\
\text { underlying the put positions }\end{array}$ & & $\begin{array}{c}-0.00801 * \\
(-1.89)\end{array}$ & & $\begin{array}{l}-0.00437 \\
(-1.16)\end{array}$ \\
\hline $\begin{array}{l}\text { Value of equity shares } \\
\text { underlying the call positions }\end{array}$ & & & $\begin{array}{l}0.0000202 \\
(0.02)\end{array}$ & $\begin{array}{l}0.000726 \\
(1.04)\end{array}$ \\
\hline $\begin{array}{l}\text { Value of equity shares } \\
\text { underlying the put positions }\end{array}$ & & & $\begin{array}{c}-0.00101 * * \\
(-2.02)\end{array}$ & $\begin{array}{c}-0.00134^{*} \\
(-1.90)\end{array}$ \\
\hline Constant & $\begin{array}{c}0.286 * * * \\
(10.26)\end{array}$ & $\begin{array}{c}0.286 * * * \\
(10.25)\end{array}$ & $\begin{array}{c}0.286 * * * \\
(10.30)\end{array}$ & $\begin{array}{c}0.288 * * * \\
(10.32)\end{array}$ \\
\hline $\begin{array}{l}\text { Observations } \\
\text { Adjusted } \mathrm{R}^{2}\end{array}$ & $\begin{array}{l}44702 \\
0.006\end{array}$ & $\begin{array}{l}44702 \\
0.007\end{array}$ & $\begin{array}{c}44702 \\
0.008\end{array}$ & $\begin{array}{c}44702 \\
0.020\end{array}$ \\
\hline
\end{tabular}




\section{Table 9: Tail Risk Timing: Evidence From the Financial Crisis in 2008}

This table reports the results on tail risk timing during the financial crisis in 2008. Panel A shows differences between aggregate hypothetical TailRisk and aggregate actual TailRisk of hedge funds' disclosed long equity holdings in March 2008 and in October 2008. Panel B compares hedge funds' number of different stocks on which put positions are held and the equivalent number and value of equity shares underlying the put positions (in millions) between March 2008 and October 2008. In Panel C, for each stock we compute (i) the number of different hedge funds that hold put positions, (ii) the overall number of equity shares held by different hedge funds underlying the put positions (in millions), and (iii) the overall value of equity shares held by different hedge funds underlying the put positions (in \$ millions) on this stock in October 2008 and regress these measures on tail risk and different stock characteristics. Finally, Panel D reports the results of univariate portfolio sorts in October 2008. We sort individual hedge funds into tercile portfolios according to (i) equity TailRisk timing ability (i.e., the difference between hypothetical TailRisk and actual TailRisk), (ii) the number of different stocks on which funds hold put positions, (iii) the equivalent number of equity shares underlying the put positions (in millions), and (iv) the equivalent value of equity shares underlying the put positions (in $\$$ millions). We compute the average excess fund returns for these portfolios as well as the (3-1) difference portfolio in October 2008. Our sample covers hedge fund firms from the Union Hedge Fund Database constructed from combining the Eureka, HFR, Morningstar, and Lipper TASS databases who report long equity and option positions to the SEC in their $13 \mathrm{~F}$ filings. ***, **, and * denotes statistical significance at the $1 \%, 5 \%$, and $10 \%$ level, respectively.

Panel A: TailRisk from Equity Holdings

\begin{tabular}{ccc}
\hline & Pre-Crisis & Crisis \\
& March 2008 & October 2008 \\
\hline Hypothetical Equity TailRisk & 0.83 & 1.19 \\
Actual Equity TailRisk & 0.83 & 1.11 \\
& & $0.08^{* * *}$ \\
Difference & 0.00 & $(3.60)$ \\
\hline
\end{tabular}

Panel B: Long Put Positions

\begin{tabular}{|c|c|c|c|}
\hline & $\begin{array}{l}\text { Number of different put } \\
\text { positions }\end{array}$ & $\begin{array}{l}\text { Number of equity shares } \\
\text { underlying the put positions } \\
\text { (in million) }\end{array}$ & $\begin{array}{c}\text { Value of equity shares } \\
\text { underlying the put } \\
\text { positions } \\
\text { (in million) }\end{array}$ \\
\hline $\begin{array}{c}\text { Pre-Crisis } \\
\text { March } 2008\end{array}$ & 4.14 & 1.51 & 26.25 \\
\hline $\begin{array}{c}\text { Crisis } \\
\text { October } 2008\end{array}$ & 5.90 & 2.71 & 36.53 \\
\hline Difference & $\begin{array}{l}1.76 * * \\
(2.03)\end{array}$ & $\begin{array}{l}1.20 * * * \\
(3.14)\end{array}$ & $\begin{array}{c}10.28 * * * \\
(4.51)\end{array}$ \\
\hline
\end{tabular}


Table 9: (Continued)

Panel C: Put Options and Stock Characteristics

\begin{tabular}{|c|c|c|c|c|c|c|}
\hline $\begin{array}{c}\text { Stock } \\
\text { Holdings-Based } \\
\text { Variables }\end{array}$ & $\begin{array}{c}\text { (1) } \\
\text { Number of } \\
\text { Hedge } \\
\text { Funds with } \\
\text { Puts }\end{array}$ & $\begin{array}{c}\text { (2) } \\
\text { Number of } \\
\text { Equity Shares } \\
\text { Held by Hedge } \\
\text { Funds }\end{array}$ & $\begin{array}{c}\text { (3) } \\
\text { Value of Equity } \\
\text { Shares Held by } \\
\text { Hedge Funds }\end{array}$ & $\begin{array}{c}\text { (4) } \\
\text { Number of } \\
\text { Hedge Funds } \\
\text { with Puts }\end{array}$ & $\begin{array}{c}\text { (5) } \\
\text { Number of } \\
\text { Equity Shares } \\
\text { Held by } \\
\text { Hedge Funds }\end{array}$ & $\begin{array}{c}\text { (6) } \\
\text { Value of Equity } \\
\text { Shares Held by } \\
\text { Hedge Funds }\end{array}$ \\
\hline Equity Tail & $1.726 * * *$ & $0.537 * *$ & $10.33 * *$ & $0.709 * * *$ & 0.112 & $5.535^{*}$ \\
\hline Risk & $(7.21)$ & $(2.11)$ & $(2.34)$ & (3.37) & $(0.38)$ & (1.83) \\
\hline Standard & & & & $0.541 * * *$ & $0.428 * * *$ & $7.462 * * *$ \\
\hline Deviation & & & & (13.09) & (7.71) & $(8.45)$ \\
\hline Skewness & & & & $\begin{array}{c}0.237 * * * \\
(5.30)\end{array}$ & $\begin{array}{c}0.307 * * * \\
(5.40)\end{array}$ & $\begin{array}{c}5.819 * * * \\
(5.96)\end{array}$ \\
\hline Kurtosis & & & & $\begin{array}{c}0.00769 * * \\
(2.05)\end{array}$ & $\begin{array}{c}0.0128^{*} \\
(1.68)\end{array}$ & $\begin{array}{c}0.0682 \\
(0.85)\end{array}$ \\
\hline Beta & & & & $\begin{array}{c}-0.0616 \\
(-0.51)\end{array}$ & $\begin{array}{l}-0.280 \\
(-1.64)\end{array}$ & $\begin{array}{c}-11.80 * * * \\
(-4.07)\end{array}$ \\
\hline Liquidity & & & & $\begin{array}{c}0.0769 * * * \\
(15.26)\end{array}$ & $\begin{array}{c}0.0600 * * * \\
(8.42)\end{array}$ & $\begin{array}{c}1.290 * * * \\
(9.70)\end{array}$ \\
\hline Size & & & & $\begin{array}{c}1.393 * * * \\
(26.65)\end{array}$ & $\begin{array}{c}0.970 * * * \\
(10.95)\end{array}$ & $\begin{array}{c}20.60 * * * \\
(11.64)\end{array}$ \\
\hline $\begin{array}{c}\text { Book-to- } \\
\text { market }\end{array}$ & & & & $\begin{array}{c}0.0752^{*} \\
(1.92)\end{array}$ & $\begin{array}{c}0.114^{*} \\
(1.70)\end{array}$ & $\begin{array}{c}2.643 * * * \\
(2.82)\end{array}$ \\
\hline $\begin{array}{l}\text { Past Yearly } \\
\text { Return }\end{array}$ & & & & $\begin{array}{c}-2.768 * * * \\
(-13.01)\end{array}$ & $\begin{array}{c}-2.143^{* * * *} \\
(-8.28)\end{array}$ & $\begin{array}{c}-37.66^{* * * *} \\
(-8.82)\end{array}$ \\
\hline Constant & $\begin{array}{c}1.114 * * * \\
(12.48)\end{array}$ & $\begin{array}{c}0.580 * * * \\
(5.92)\end{array}$ & $\begin{array}{c}9.764 * * * \\
(5.77)\end{array}$ & $\begin{array}{c}-17.25 * * * \\
(-24.32)\end{array}$ & $\begin{array}{c}-12.33 * * * \\
(-10.37)\end{array}$ & $\begin{array}{c}-257.9 * * * \\
(-11.22)\end{array}$ \\
\hline Observations & 4211 & 4211 & 4211 & 3801 & 3801 & 3801 \\
\hline Adjusted $\mathrm{R}^{2}$ & 0.019 & 0.002 & 0.002 & 0.472 & 0.204 & 0.239 \\
\hline
\end{tabular}

Panel D: Fund Firm Performance Differences in October 2008

\begin{tabular}{ccccc}
\hline & $\begin{array}{c}\text { Equity TailRisk } \\
\text { Timing }\end{array}$ & $\begin{array}{c}\text { Number of different } \\
\text { put positions }\end{array}$ & $\begin{array}{c}\text { Number of equity } \\
\text { shares underlying the } \\
\text { put positions } \\
\text { (in million) }\end{array}$ & $\begin{array}{c}\text { Value of equity shares } \\
\text { underlying the put } \\
\text { positions } \\
\text { (in million) }\end{array}$ \\
\hline PF 1 & $-9.57 \%$ & $-10.06 \%$ & $-9.11 \%$ & $-8.88 \%$ \\
PF 2 & $-8.14 \%$ & $-6.96 \%$ & $-7.50 \%$ & $-6.90 \%$ \\
PF 3 & $-5.34 \%$ & $-5.00 \%$ & $-5.05 \%$ & $-5.27 \%$ \\
PF3 - PF1 & $4.23 \% * * *$ & & & $3.61 \% *$ \\
& $(2.95)$ & $5.06 \% * * *$ & $4.06 \% * * *$ & $(1.82)$ \\
\hline
\end{tabular}

